\title{
A preliminary screening and characterization of suitable acids for sandstone matrix acidizing technique: a comprehensive review
}

\author{
Leong Van Hong ${ }^{1} \mathbb{D} \cdot$ Hisham Ben Mahmud ${ }^{1}$
}

Received: 23 January 2018 / Accepted: 4 June 2018 / Published online: 11 June 2018

(c) The Author(s) 2018

\begin{abstract}
Matrix acidizing is a broadly developed technique in sandstone stimulation to improve the permeability and porosity of a bottom-hole well. The most popular acid used is mud acid (HF-HCl). It is a mixture of hydrofluoric acid and hydrochloric acid. However, one of the conventional problems in sandstone acidizing is that mud acid faces significant issues at high temperature such as rapid rate of reaction, resulting in early acid consumption. This downside has given a negative impact to sandstone acidizing as it will result in not only permeability reduction, but can even extend to acid treatment failure. So, the aim of this study is to provide a preliminary screening and comparison of different acids based on the literature to optimize the acid selection, and targeting various temperatures of sandstone environment. This paper has comprehensively reviewed the experimental works using different acids to understand the chemical reactions and transport properties of acid in sandstone environment. The results obtained indicated that fluoroboric acid $\left(\mathrm{HBF}_{4}\right)$ could be useful in enhancing the sandstone acidizing process, although more studies are still required to consolidate this conclusion. $\mathrm{HBF}_{4}$ is well known as a low damaging acid for sandstone acidizing due to its slow hydrolytic reaction to produce HF. This would allow deeper penetration of the acid into the sandstone formation at a slower rate, resulting in higher porosity and permeability enhancement. Nevertheless, little is known about the effective temperature working range for a successful treatment. Considering the pros and cons of different acids, particularly those which are associated with $\mathrm{HF}$ and $\mathrm{HBF}_{4}$, it is recommended to perform a comprehensive analysis to determine the optimum temperature range and effective working window for sandstone acidizing before treatment operation. Prior to sandstone acid stimulation, it is essential to predict the feasibility of acid selected by integrating the effects of temperature, acid concentration and injection rate. Therefore, this manuscript has thrown light into the research significance of further studies.
\end{abstract}

Keywords Well stimulation $\cdot$ Sandstone matrix acidizing $\cdot$ Mud acid $\cdot$ Fluoroboric acid $\cdot$ High temperature $\cdot$ Core flooding experiment

\begin{tabular}{|c|c|c|c|}
\hline \multicolumn{2}{|c|}{ Abbreviations } & \multirow{2}{*}{$\begin{array}{l}\mathrm{K}_{0.5} \mathrm{Na}_{0.5} \mathrm{AlSi}_{3} \mathrm{O}_{8} \\
\mathrm{CaMg}\left(\mathrm{CO}_{3}\right)_{2}\end{array}$} & Feldspar \\
\hline K & Potassium & & Dolomite \\
\hline $\mathrm{F}$ & Fluorine & $\mathrm{FeCO}_{3}$ & Siderite \\
\hline $\mathrm{Na}$ & Sodium & $\mathrm{Mg}_{6} \mathrm{Si}_{4} \mathrm{O}_{10}(\mathrm{OH})_{8}$ & Chlorite \\
\hline $\mathrm{Ca}$ & Calcium & $\mathrm{KAl}_{3} \mathrm{Si}_{3} \mathrm{O}_{10}(\mathrm{OH})_{2}$ & Mica/illite \\
\hline $\mathrm{Al}$ & Aluminum & $\mathrm{H}_{2} \mathrm{O}$ & Water \\
\hline $\mathrm{Fe}$ & Iron & $\mathrm{Fe}(\mathrm{OH})_{2}$ & Iron hydroxide \\
\hline $\mathrm{Mg}$ & Magnesium & $\mathrm{AlCl}_{3}$ & Aluminum chloride \\
\hline${ }^{11} \mathrm{~B}$ & Boron-11 & $\mathrm{Al}_{2} \mathrm{SiO}_{5}$ & Aluminosilicates \\
\hline${ }^{19} \mathrm{~F}$ & Fluorine-19 & $\mathrm{HF}$ & Hydrofluoric acid \\
\hline $\mathrm{SiO}_{2}$ & Quartz & $\mathrm{HCl}$ & Hydrochloric acid \\
\hline & & $\mathrm{HBF}_{4}$ & Fluoroboric acid \\
\hline$\triangle \mathrm{L}$ & stgrad.curtin.edu.my & $\begin{array}{l}\mathrm{CH}_{3} \mathrm{COOH} \\
\mathrm{HCOOH}\end{array}$ & $\begin{array}{l}\text { Acetic acid } \\
\text { Formic acid }\end{array}$ \\
\hline 1 & ring Department, Curtin University, Miri, & $\begin{array}{l}\mathrm{C}_{6} \mathrm{H}_{8} \mathrm{O}_{7} \\
\mathrm{CH}_{3} \mathrm{OH}\end{array}$ & $\begin{array}{l}\text { Citric acid } \\
\text { Methanol }\end{array}$ \\
\hline
\end{tabular}




\begin{tabular}{|c|c|}
\hline $\mathrm{HCOOCH}_{3}$ & Methyl formate \\
\hline $\mathrm{NH}_{4} \mathrm{Cl}$ & Ammonium chloride \\
\hline $\mathrm{NH}_{4} \mathrm{~F}$ & Ammonium fluoride \\
\hline $\mathrm{NH}_{4}^{+}$ & Ammonium cation \\
\hline $\mathrm{HCOO}^{-}$ & Formate anion \\
\hline $\mathrm{HBF}_{3} \mathrm{OH}$ & Borofluoric acid \\
\hline $\mathrm{HBF}_{2}(\mathrm{OH})_{2}$ & Dihydroxyfluoroboric acid \\
\hline $\mathrm{HBF}(\mathrm{OH})_{3}$ & Trihydroxyfluoroboric acid \\
\hline $\mathrm{H}_{3} \mathrm{BO}_{3}$ & Boric acid \\
\hline APC & Aminopolycarboxylic acid \\
\hline EDG & Ethanol diglycine \\
\hline NTA & Nitrilotriacetic acid \\
\hline APCA & Aminopolycarboxylic acid \\
\hline HACA & Hydroxethylaminocarboxylic acid \\
\hline GLDA & Glutamic acid $N, N$-diacetic acid \\
\hline Na-GLDA & $\begin{array}{l}\text { Sodium glutamic acid } N, N \text {-diacetic } \\
\text { acid }\end{array}$ \\
\hline EDTA & Ethylenediaminetetraacetic acid \\
\hline HEIDA & Hydroxyethyliminodiacetic acid \\
\hline HEDTA & $\begin{array}{l}\text { Hydroxyethylethylenediaminetriacetic } \\
\text { acid }\end{array}$ \\
\hline $\mathrm{Na}_{3} \mathrm{HEDTA}$ & $\begin{array}{l}\text { Sodium hydroxyethylethylenediamin- } \\
\text { etriacetic acid }\end{array}$ \\
\hline EOR & Enhanced oil recovery \\
\hline HSE & Health, safety and environment \\
\hline НTHP & High temperature high pressure \\
\hline HTDP & High temperature deep penetrating \\
\hline BOPD & Barrel oil per day \\
\hline BLPD & Barrel liquid per day \\
\hline BHST & Bottom-hole static temperature \\
\hline Poro-Perm & Porosity-permeability \\
\hline SEM & Scanning electron microscope \\
\hline FESEM & $\begin{array}{l}\text { Field emission scanning electron } \\
\text { microscope }\end{array}$ \\
\hline CT scan & Computerized tomography scan \\
\hline $\mathrm{ICP}$ & Induced coupled plasma \\
\hline NMR & Nuclear magnetic resonance \\
\hline XRD & $\mathrm{X}$-ray diffraction \\
\hline OES & Optical emission spectrographic \\
\hline EDS & Energy-dispersive X-ray spectroscopy \\
\hline TSP & Thin section petrographic \\
\hline FAAS & Flame atomic absorption spectroscopy \\
\hline MOHE & Ministry of Higher Education \\
\hline FRGS & Fundamental Research Grant Scheme \\
\hline FOES & Faculty of Engineering and Science \\
\hline
\end{tabular}

\section{List of symbols}

$\%$

$\mathrm{wt} \%$

${ }^{\circ} \mathrm{F}$

${ }^{\circ} \mathrm{C}$

$\mathrm{m}$

$\mathrm{md} / \mathrm{mD}$
$\mathrm{ml}$
Milliliter
$\mathrm{pH}$
Potential of hydrogen

\section{Introduction}

In the recent years, the energy demand around the globe has continued to grow. According to a prediction, the aggregate requirement of energy would be $40 \%$ more in 2020 than in the present (Aboud et al. 2007). Hence, the oil and gas sector continues to expand the limit and boundary in terms of technology and commercial aspects. Innovative and feasible technology development in well stimulation and enhanced oil recovery (EOR) become one of the primary focuses in the oil field.

Matrix acidizing is a broadly developed technique in well stimulation. During acidizing process, acids are injected into the bottom-hole well with a pressure below the formation fracture pressure. Ever since the mid-1960s, sandstone matrix acidizing has gained wide application and played an important role in the petroleum industry (Kalfayan and Metcalf 2000). Different acids had been developed to stimulate depleted sandstone reservoir after many years of oil and gas production. Acid is playing an important role to improve the porosity and permeability of a reservoir formation. The other function of acid is to reduce the formation damage as well as enhancing the productivity of the well (Kalfayan 2008).

The most popular acid used in sandstone stimulation treatment is the mud acid. Hydrofluoric acid (HF) and hydrochloric acid $(\mathrm{HCl})$ are being mixed and combined to form the mud acid. Indeed, this is because HF can effectively dissolve the minerals present in a sandstone matrix whereas $\mathrm{HCl}$ is well known in precipitation control (Smith and Hendrickson 1965). Nevertheless, high temperature well acidizing is of utmost importance. Recently, reservoirs with great depth and temperature have become the center of attention to exploration of new oil and gas reserves (Al-Harthy et al. 2009). Wells are producing from deep hot reservoir, with a temperature higher than $200^{\circ} \mathrm{F}$. These reservoirs have temperature range from $100^{\circ} \mathrm{F}$ and could go up to above $500{ }^{\circ} \mathrm{F}$. In recent years, the evolution of matrix acidizing, focusing on high-temperature wells had limited the use of mud acid. So, all aspects in acid stimulation such as efficiency of acid, corrosion rate and stability must be improved to ensure successful well treatment (Gidley 1985).

There are some significant problems of using conventional mud acid at a temperature higher than $200^{\circ} \mathrm{F}$. At hightemperature conditions, mud acid can lead to rapid rate of reaction with the mineral content in the sandstone matrix (Shuchart and Gdanski 1996; Al-Dahlan et al. 2001). As a result, the acidizing process becomes inefficient and may even fail mainly due to early and rapid consumption of the acid (Al-Harthy et al. 2009). Moreover, the use of HF acid 
during well stimulation was discovered to cause significant reduction of the formation compressive strength, especially formation with high clay content. Consequently, the formation will disintegrate, resulting in porosity and permeability reduction (Thomas and Crowe 1981). In addition, mud acid has highly corrosive properties, making it a hazardous acid that is difficult for health and safety control. Therefore, the acidizing treatment has become less efficient. It is noticeable that high-temperature sandstone acidizing technique is in growing demand and, therefore, has become the attractive spot of current research.

Against this background, it is critical to develop new acid combination, which can mitigate the issues caused by conventional mud acid at elevated temperatures. At the same time, the new acid combination has a role in formation porosity and permeability enhancement, ensuring positive economic returns. There have been a number of acids that had been developed and used in the sandstone well stimulation. These acids include the most popular mud acid, chelating agents, retarded acids, organic acids as well as fluoroboric acid $\left(\mathrm{HBF}_{4}\right)$.

The primary aim of this paper is to comprehensively and critically review all the experimentations that were performed using all these different types of acid. In this paper, a preliminary screening and comparison of different acids based on the literature studies were conducted to optimize the selection of acid, targeting various temperatures of sandstone condition. Synchronously, an evaluation of the pros and cons of the acids used in association with sandstone formation were clearly addressed and highlighted.

In the past, many researchers had proven various advantages that were offered by fluoroboric acid $\left(\mathrm{HBF}_{4}\right)$ and phosphoric acid $\left(\mathrm{H}_{3} \mathrm{PO}_{4}\right)$ when compared to the mud acid. $\mathrm{HBF}_{4}$ can produce $\mathrm{HF}$ through slow hydrolysis process. On the other hand, $\mathrm{H}_{3} \mathrm{PO}_{4}$ functions like a buffer acid, which enables a deeper penetration of acid into the sandstone matrix before being spent. Similarly, both these acids result in higher permeability increase, lower strength reduction of the core plugs and relatively lower corrosiveness. Despite this, there are few studies indicating the precise temperature range, in which $\mathrm{HBF}_{4}$ can be suitably applied, resulting in successful sandstone acid treatment.

Therefore, considering all the aspects of acids such as the effects of temperature, acid concentration and injection rate in particular, it is recommended to carry out a detailed optimization analysis based on parametric study or sensitivity analysis approach. This is especially crucial to accurately determine the optimum temperature range to ensure a highly positive sandstone acidizing treatment results. Hence, this manuscript has provided an outlook or insight into the research significance of further studies. The future analytical work which can be done to characterize the acids was also proposed.

\section{Background}

\section{Well stimulation}

The operations in oil and gas field such as drilling, completion, workover, production and other long-time operations resulted in the deposition of minerals near wellbore over time. Consequently, this results in production depletion due to formation damage occurring around the wellbore (Williams et al. 1979). Therefore, field engineers must determine the solution to perform well treatment to bring up the productivity of the wells to ensure economic returns. One such solution is known as well stimulation (Schechter 1992; Economides et al. 2013).

Well stimulation is a technique applied to enhance the production of oil or gas from the reservoir to the wellbore. It has played an important role in the development of oil and gas wells, ensuring good economic returns (Cipolla 2003). In recent years, many creative and innovative approaches are used to treat the wells (Coulter 2011). Hydraulic fracturing enhances the oil and gas production by creating fracture in the reservoir well through injection of hydraulic fluid at a pressure higher than that of the formation pressure (Economides et al. 2013). In the industry, hydraulic fracturing still represents the higher interest in well stimulation. However, acidizing also plays a major role in different case studies. The use of main acid like hydrochloric acid and other acids such as hydrofluoric acid, formic acid and acetic acid is important (Coulter 2012).

The most common stimulation techniques include hydraulic fracturing, matrix acidizing and fracture acidizing. Each of these techniques has different advantages and limitations in stimulating a well. Figure 1 shows the penetration of acid being injected into a sandstone matrix during acidizing.

Often, questions have been raised upon the choice of fracturing or acidizing. In fact, the decision whether to fracture a well or acidize it depends on various factors which include the formation geology, production history and well-intervention objectives (Al-Harthy et al. 2009).

The loose formations with relatively better porosity and permeability require less intensive hydraulic fracturing, whereas tight formations with relatively lower porosity and permeability require high-intensive hydraulic fracturing. The formation permeability is a very important parameter to be considered before performing hydraulic fracturing (Holman 1982). However, for loosely bound formations, hydraulic fracturing has high tendency to cause formation collapse due to the overburden pressure. Furthermore, the formation with damage due to drilling and production is not recommended to be stimulated with hydraulic fracturing. Instead, matrix acidizing is more suitable for such formation (Houseworth 2014). 
Fig. 1 Pore-scale figure of matrix acidizing process when the acid is being injected and acid passes through the pore space illustrated by Veldkam and Boxem (2015)

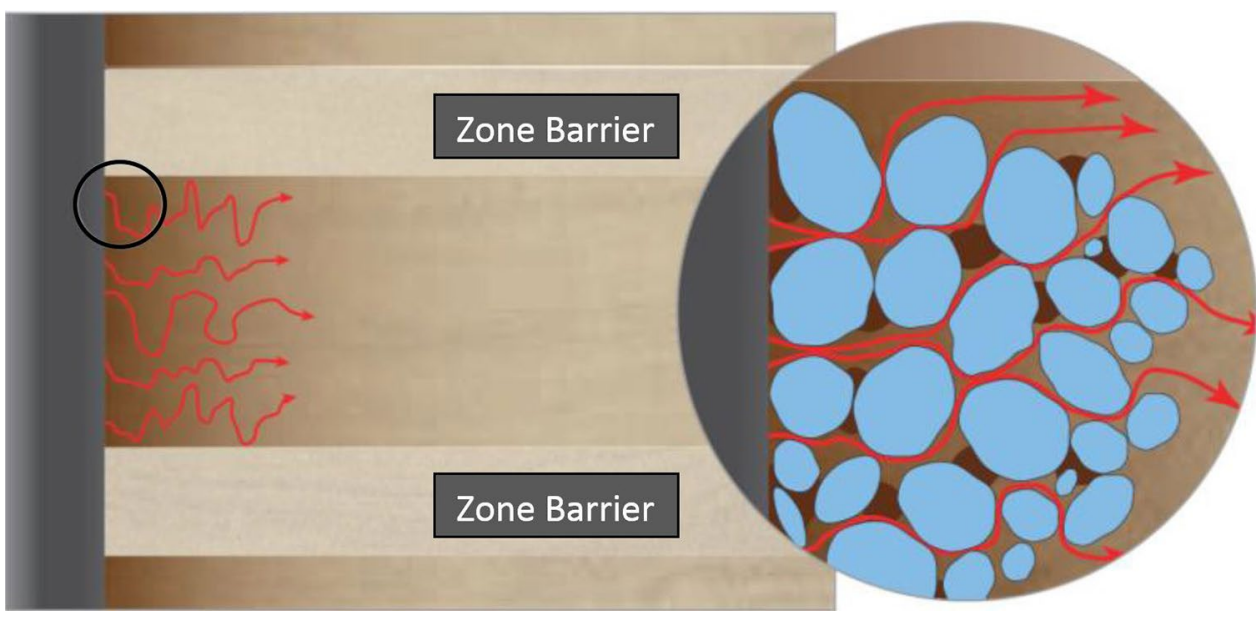

In common practice, acid fracturing is applied to carbonate formations, which are rich in limestones and dolomites (King 1986; Milligan 1994). The acid is channeled into the fracture surface to prevent it from being closed by overburden stress. Acid fracturing is more successful to be applied in carbonate formations with high natural fractures and high permeability (Houseworth 2014).

For sandstone formations, matrix acidizing tends to have limited penetration depth. Typically, matrix acidizing has a shorter penetration depth of about $0.3 \mathrm{~m}$ in comparison to hydraulic fracturing and fracture acidizing. Usually, it is not used for formations with low permeability because it requires long deep penetration depth to be successfully stimulated. As such, hydraulic fracturing is more suitable in this case. However, matrix acidizing is viable and effective when the well is naturally fractured and is normally used to remove the formation damage near the well, which prevents flow into the well. Hence, the acid can dissolve the plugging minerals in the production flow path (Economides et al. 2013). Therefore, different well stimulation methods as shown in Fig. 2 have different practicality and suitability for different formations.

\section{Introduction to sandstone matrix acidizing}

\section{Sandstone mineralogy}

Sandstone is a clastic sedimentary rock. Sometimes, it is also called arenite. Sandstone is made up of silica, $\mathrm{SiO}_{2}$ and many silicate minerals. The main compositions of a sandstone matrix include quartz, feldspar and different forms of clay. Zeolite may also be present in a sandstone although it is rare (Muecke 1982). Table 1 shows the concentration of different minerals present in a typical Berea sandstone core sample used in the industry for core flooding test. Figure 3 shows the mineral components of a sandstone rock.

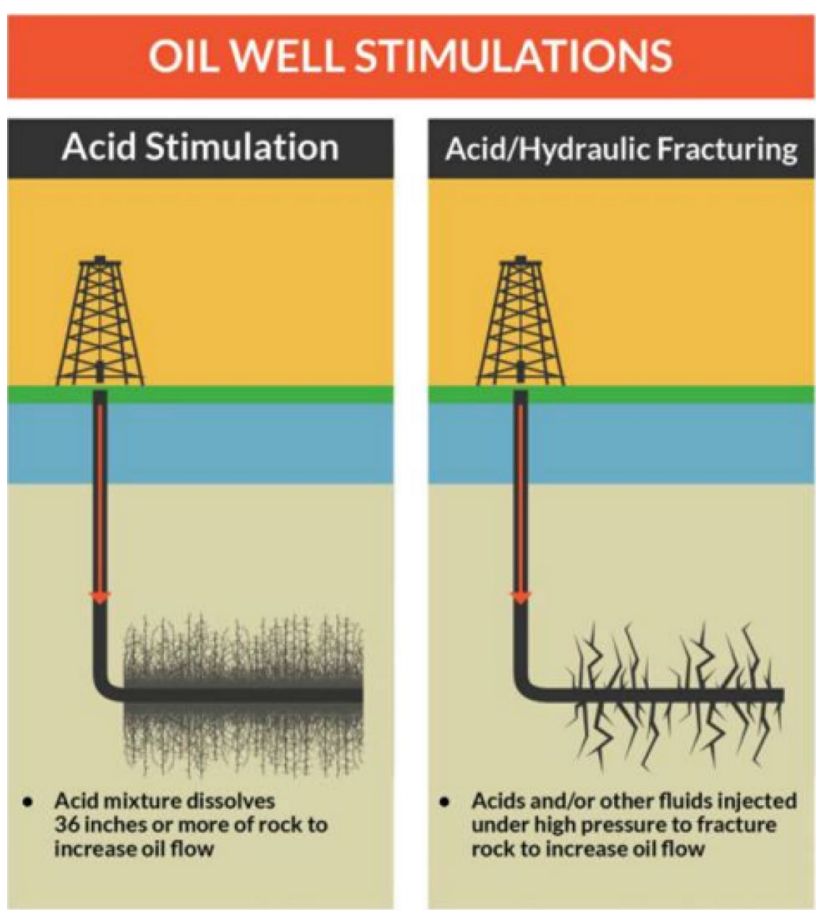

Fig. 2 Oil well stimulation illustration

Table 1 Mineralogy of a typical Berea sandstone (Al-Shaalan and Nasr-El-Din 2000)

\begin{tabular}{lcl}
\hline Mineral & Concentration (wt\%) & Chemical formulae \\
\hline Quartz & 75 & $\mathrm{SiO}_{2}$ \\
Feldspar & 5 & $\mathrm{~K}_{0.5} \mathrm{Na}_{0.5} \mathrm{AlSi}_{3} \mathrm{O}_{8}$ \\
Dolomite & 5 & $\mathrm{CaMg}_{\left(\mathrm{CO}_{3}\right)_{2}}$ \\
Siderite & 5 & $\mathrm{FeCO}_{3}$ \\
Chlorite & 5 & $\mathrm{Mg}_{6} \mathrm{Si}_{4} \mathrm{O}_{10}(\mathrm{OH})_{8}$ \\
Mica/lllite & 5 & $\mathrm{KAl}_{3} \mathrm{Si}_{3} \mathrm{O}_{10}(\mathrm{OH})_{2}$ \\
\hline
\end{tabular}




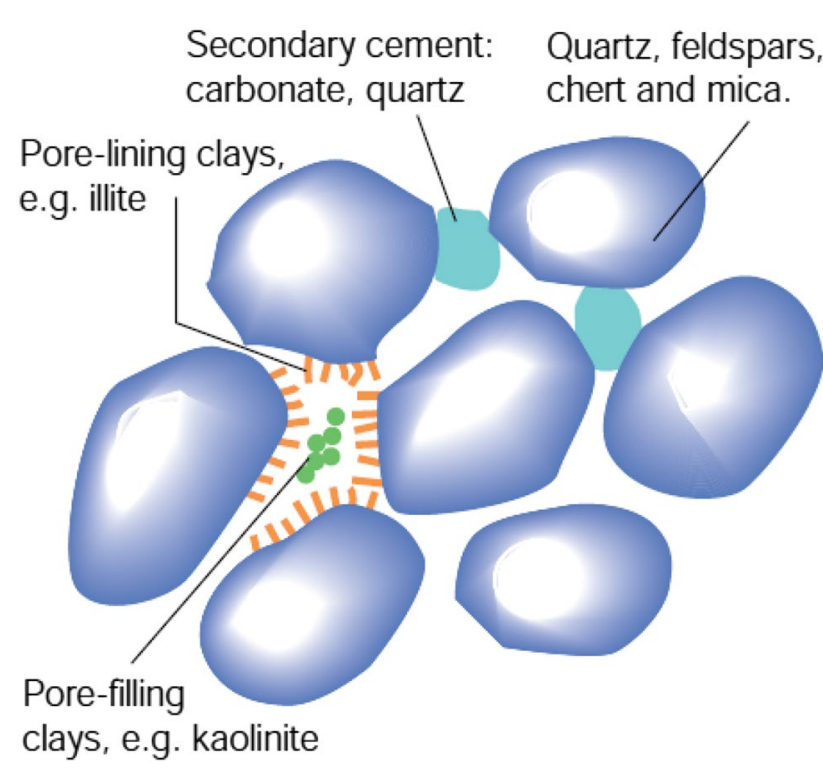

Fig. 3 Constituents of sandstone, all of which are soluble in $\mathrm{HCl}-\mathrm{HF}$ mud acid system as described by Crowe et al. (1992)

When reacting with HF acid, clays and feldspar have higher dissolution rate than quartz. This is due to the characteristic of quartz which has a more stable structure and relatively lower specific surface area.

\section{The practice in sandstone matrix acidizing}

The main purpose of matrix acidizing is to enhance the production of a sandstone well and to reduce its skin. This technique has been used for many years to stimulate reservoir formations by changing the rock properties, which are the porosity and permeability (Crowe et al. 1992). During operation, the injection pressure of the acid is lower than the formation fracture pressure. When the acid is injected, it dissolves all the minerals within the soluble reservoir rock. This creates more pore spaces, thus increasing the flow rate of fluid from the reservoir formation layers to the wellbore (Ali et al. 2004). In the early stage, the use of mud acid in sandstone acidizing is a major breakthrough in the area of well stimulation technique (Kalfayan 2008). The commonly practiced acid composition during operation is 3\% $\mathrm{HF}$ and $12 \% \mathrm{HCl}$ (Smith and Hendrickson 1965; Gidley 1985). Table 2 shows the chemical compositions of minerals that are present in a sandstone and their solubility in $\mathrm{HCl}$ and $\mathrm{HCL}-\mathrm{HF}$ mud acid.

In a typical operation, sandstone matrix acidizing is divided into three main phases (Hill et al. 1981, 1994; Zeit 2005; Nasr-El-Din et al. 2005), which are discussed as follows:
Table 2 Solubility of sandstone minerals (Portier et al. 2007)

\begin{tabular}{lll}
\hline Minerals & Solubility & \\
\cline { 2 - 3 } & HCl & HCL-HF \\
\hline Quartz & No & Very low \\
Feldspar & No & Low to moderate \\
Mica & No & Low to moderate \\
Kaolinite & No & High \\
Illite & No & High \\
Smectite & No & High \\
Chlorite & Low to moderate & High \\
Calcite & High & High, but $\mathrm{CaF}_{2}$ precipitation \\
Dolomite & High & High \\
Ankerite & High & High \\
Siderite & High & High \\
\hline
\end{tabular}

1. A pre-flush phase to dissolve sodium (Na), potassium $(\mathrm{K})$ and calcium $(\mathrm{Ca})$ ions that will have reactions with the silica, forming insoluble silicates.

2. A main flush phase to dissolve the silicates, quartz, feldspar, clay as well as undissolved carbonates after preflush.

3. An after-flush phase to remove the spent acid to keep the wettability in its original state and clean the formation.

\section{The treatment design of matrix acidizing}

Kalfayan and Metcalf (2000) emphasized that the development of acid treatment design is of paramount importance to a successful sandstone acidizing treatment. Generally, the design procedure should be based on the conventional treatment steps. Technical analyses and statistical survey were conducted extensively over 650 cases of matrix stimulation treatments in 9 countries. The studies revealed that incorrect field procedure was the main reason causing the acidizing failure (Paccaloni and Tambini 1993). However, the specific design procedure should remain open and could be reduced to include only necessary steps, depending on case by case basis. A few successful applications of field case study had been demonstrated in the Netherlands (van Domelen et al. 1997), Saudi Arabia (Hashem et al. 1999), North America, South America and Far East (Kalfayan and Metcalf 2000).

During a matrix acidizing operation, all information such as well history, laboratory test data as well as previous operation experience are important for an engineer to decide the acidizing treatment fluid. To ensure the success of a matrix acidizing treatment, a comprehensive reservoir characterization workflow approach is essential (Schmid et al. 2016). Every detail from treatment design until execution must be considered carefully. McLeod (1984) recommended the treatment fluid selection guideline for sandstone acidizing, aiming to enhance the permeability.

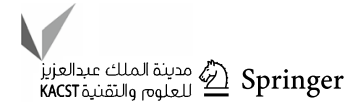


Table 3 Guideline for treatment fluid selection (Crowe et al. 1992)

\begin{tabular}{lll}
\hline Condition & Main acid & Pre-flush \\
\hline HCl solubility $(>20 \%)$ & Use $\mathrm{HCl}$ only & \\
High permeability $(>100 \mathrm{md})$ & & \\
High quartz $(80 \%)$, low clay $(<5 \%)$ & $12 \% \mathrm{HCl}, 3 \% \mathrm{HF}$ & $15 \% \mathrm{HCl}$ \\
High feldspar $(>20 \%)$ & $13.5 \% \mathrm{HCl}, 1.5 \% \mathrm{HF}$ & $15 \% \mathrm{HCl}$ \\
High clay $(>10 \%)$ & $6.5 \% \mathrm{HCl}, 1 \% \mathrm{HF}$ & Sequestered $5 \% \mathrm{HCl}$ \\
High iron chloride clay & $3 \% \mathrm{HCl}, 0.5 \% \mathrm{HF}$ & Sequestered $5 \% \mathrm{HCl}$ \\
Low permeability $(<10 \mathrm{md})$ & & \\
Low clay $(<5 \%)$ & $6 \% \mathrm{HCl}, 1.5 \% \mathrm{HF}$ & $7.5 \% \mathrm{HCl}$ or $10 \%$ acetic acid \\
High chlorite & $3 \% \mathrm{HCl}, 0.5 \% \mathrm{HF}$ & $5 \%$ acetic acid \\
\hline
\end{tabular}

Table 4 Alternate sandstone acid procedures established by Portier et al. (2007)

\begin{tabular}{ll}
\hline Well and formation conditions & Treatment fluid recommendation \\
\hline $\begin{array}{l}\text { Bottomhole treating tempera- } \\
\text { tures }>100{ }^{\circ} \mathrm{C}\end{array}$ & $1.5 \% \mathrm{HF}+13.5 \% \mathrm{HCl}$ \\
$\begin{array}{l}\text { Permeability }<5 \mathrm{md} \\
\text { Quartz content }\end{array}$ & $1.5 \% \mathrm{HF}+13.5 \% \mathrm{HCl}$ \\
Over $90 \%$ & $3 \% \mathrm{HF}+12 \% \mathrm{HCl}$ \\
$50-90 \%$ & $3 \% \mathrm{HF}+12 \% \mathrm{HCl}$ or retarded $\mathrm{HF}$ \\
Feldspar, $15-30 \%$ & $1.5 \% \mathrm{HF}+13.5 \% \mathrm{HCl}$ \\
Chlorite clay & \\
$1-5 \%$ & $3 \% \mathrm{HF}+10 \%$ acetic acid \\
$<5 \%$ & $1.5 \% \mathrm{HF}+10 \%$ acetic or formic acid \\
\hline
\end{tabular}

This guideline provided the choices for acid concentration and was formed based on different level of rock permeability, clay and silt content. Table 3 shows the guideline for treatment fluid selection. Portier et al. (2007) later also suggested alternative sandstone acid procedures for specific formation conditions as shown in Table 4.

\section{The use of additives in matrix acidizing}

Matrix acidizing can cause a number of well problems such as the release of fine particles, the generation of precipitants, the formation of emulsions, the generation of sludge and also the corrosion of steel (O'Driscoll et al. 2005; Dehghani 2010; Rabie and Nasr-El-Din 2015). For instance, Hanafy et al. (2015) and Hanafy and Nasr-El-Din (2016) deducted that fines migration that was induced by clay caused porosity reduction of $40 \%$. At high temperatures of 150 and $250{ }^{\circ} \mathrm{F}$, fines migration became more sensitive to hydrochloric acid, causing more severe porosity reduction, especially at the outlet part of the sandstone core. There are a list of acid additives that have been used during matrix acidizing to solve some of the common problems that exist (Bybee 2003). Table 5 shows the summary of additives used in matrix acidizing and their functions.

\section{Sandstone channeling or wormholing}

Wormholing pattern is common in carbonate acidizing, whereas for sandstone acidizing, a uniform face dissolution pattern is observed and no preferential flow path is being
Table 5 Summary of the additives used in matrix acidizing and their functions

\begin{tabular}{ll}
\hline Acid additives & Functions \\
\hline Corrosion inhibitors & $\begin{array}{l}\text { To reduce or retard the rate of corrosion of steel by acid } \\
\text { To create an inhibitory film on the metal surface } \\
\text { To protect the acid pumping and handling equipment } \\
\text { To protect the equipment and tool such as casing, pump and valve } \\
\text { To keep clay and fines in suspension } \\
\text { To prevent migration and swelling of clays } \\
\text { To place the reactive fluid evenly } \\
\text { To bracket the interval exposed to the acidizing fluid } \\
\text { Diverting agents } \\
\text { To dissolve the corrosion products in the casing or tubing } \\
\text { To dissolve the iron minerals in the well } \\
\text { To lower the surface and interfacial tensions } \\
\text { To change or maintain the wettability of the wells } \\
\text { To break and weaken the emulsions }\end{array}$ \\
\end{tabular}


generated. It is uncommon to generate wormholes especially in homogeneous sandstone formation. This due to low rate of reaction between the acid HF and the quartz, which is the major minerals present in the sandstone (Xie et al. 2005).

Nevertheless, several literature research studies indicated that a channeling pattern, which is similar to carbonate wormholing could occur during sandstone acidizing process. If the sandstone is highly heterogeneous, then a high permeability fine-scale channeling patter would exist (Wehunt et al. 1993). Figures 4 and 5 show the wormholes generated in Bandera and Berea sandstone core flooding experiment conducted by Lamb (1998), respectively.

According to the sandstone core flooding experiment conducted by Kalfayan and Metcalf (2000), it is also indicated that some sandstone channels or wormholes were created after being treated with 6 and $9 \mathrm{wt} \% \mathrm{HF}$, as shown in Fig. 6. The results of laboratory investigation indicated that lower rate of acid injection is a positive factor to generate wormholes in sandstone.

\section{Literature review of experimental studies}

The choices of acid and additives selection are made based on the characteristics of reservoir rock as well as the main purpose of the stimulation (McLeod 1984). There are many reported experimentations that carry out investigations on the efficiency of various kinds of acid used in sandstone acidizing. A critical review of these significant studies has been reported. Therefore, the outcomes of this study have basically provided a conceptual framework for the setup and

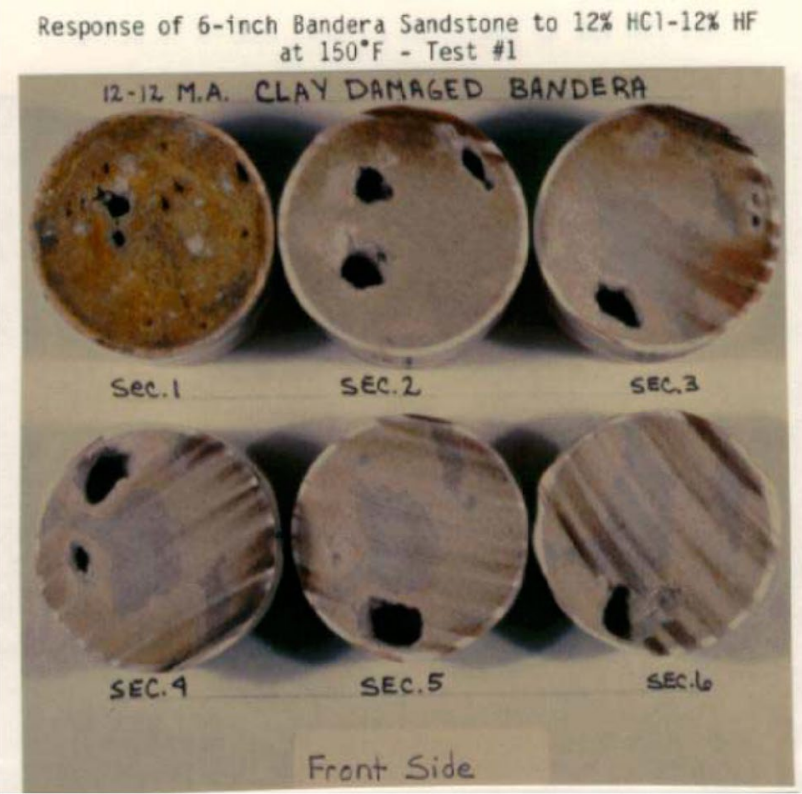

Fig. 4 Wormholes in Bandera sandstone by Lamb (1998)

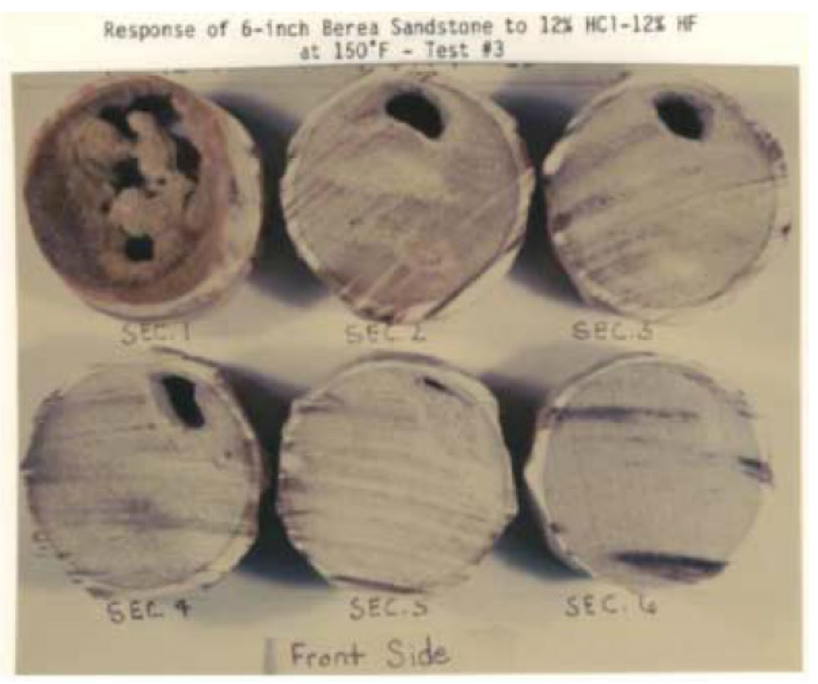

Fig. 5 Wormholes in Berea sandstone by Lamb (1998)

planning of experimental and numerical works that are recommended in the future.

\section{Mud acid (HF-HCl)}

Thomas et al. (2001) performed core flooding on Jauf core samples using $\mathrm{HCl}$ and acetic acid in the pre-flush at
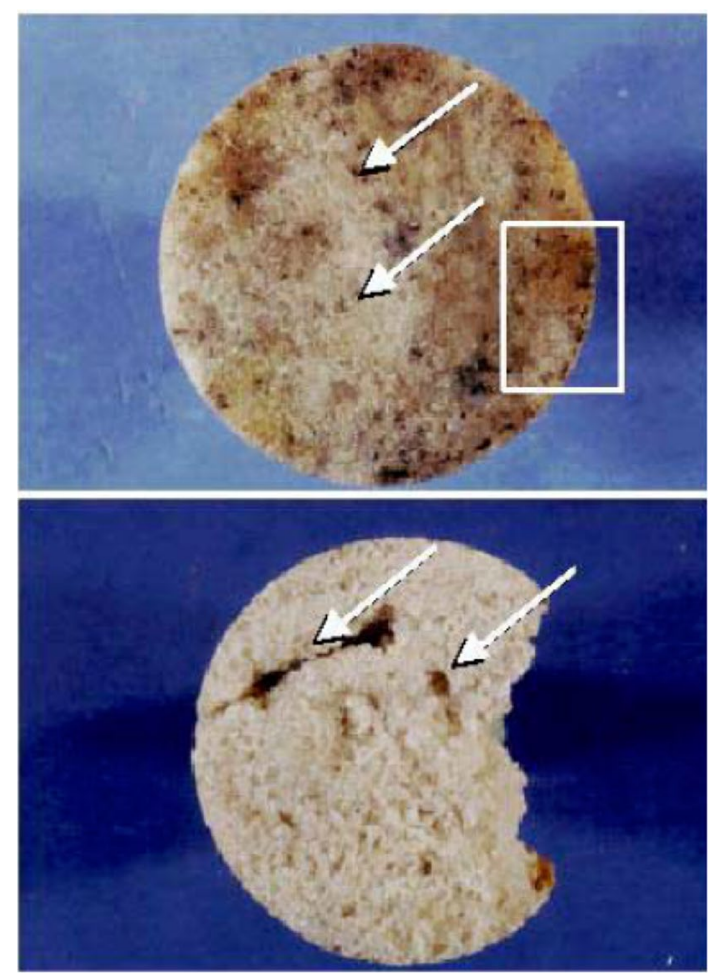

Fig. 6 Wormholes in South American sandstone by Kalfayan and Metcalf (2000) 
$150{ }^{\circ} \mathrm{C}$. The results reflected the importance of the pre-flush acid used before the mud acid due to the channels created. Channeling effects had significantly enhanced the permeability during the main acid application. Then, Thomas et al. (2002a) also investigated the effect of concentration ratio of mud acid on the change in permeability of both Jauf and Berea core samples. The results are shown in Table 6.

Nevito Gomez (2006) had designed, set up and tested matrix acidizing apparatus on conventional mud acid. The experiment was conducted on Berea sandstone core at both room temperature and at high temperature of $100{ }^{\circ} \mathrm{F}$. At room temperature, higher flow rate resulted in higher permeability enhancement, whereas at $100{ }^{\circ} \mathrm{F}$, the optimum flow rate was determined to be $30 \mathrm{ml} / \mathrm{ml}$.

Gomaa et al. (2013) and Wang et al. (2013) had investigated the effect of mud acid concentration ratio on the change in permeability of the sandstone core matrix at a temperature of $180{ }^{\circ} \mathrm{F}$. There are four different mixtures of mud acid concentration ratio, which include $1.9 \% \mathrm{HF}+15 \%$ $\mathrm{HCl}, 2.3 \% \mathrm{HF}+10 \% \mathrm{HCl}, 2.6 \% \mathrm{HF}+5 \% \mathrm{HCl}$ and $2.8 \%$ $\mathrm{HF}+3 \% \mathrm{HCl}$, respectively. All of these were tested using the core sample by applying the core flooding method. The experimental results indicated that all four acid mixing ratios can positively increase the permeability of the core sample. Nevertheless, it was observed that the result of permeability increases when the $\mathrm{HF}-\mathrm{HCl}$ ratio increases. At the same time, there was also a reduction in the acid injection volume required.

Abdelmoneim and Nasr-El-Din (2015) determined the optimum HF concentration for high-temperature sandstone formations. High temperatures of 280 and $325^{\circ} \mathrm{F}$ were used to conduct the core flooding tests on both Bandera core and Grey Berea core. Based on the result, the correlation between the optimum HF concentration and mineralogy was formed as an inverse relationship as shown in Fig. 7. Retarded acid was suggested for temperatures higher than $300^{\circ} \mathrm{F}$.

Al-Harthy et al. (2009) stated that mud acid had proven its performance and effectiveness in sandstone acidizing, thus gaining popularity. However, it was reported to result in rapid rate of reaction when the temperature was increased to $200{ }^{\circ} \mathrm{F}$. This is because of the rapid kinetics of secondary and tertiary precipitation reactions at such high temperature. This reduced the inefficiency of sandstone acidizing because of undesirably early consumption of the acids. This was also the main reason causing acid treatment to fail in many cases. Furthermore, significant reduction of compressive strength of the formation with high clay content after being treated with HF caused the formation to disintegrate (Thomas and Crowe 1981).

$\mathrm{HCl}$ played an important role in mud acid as it leaves no insoluble products from the reactions with the minerals. In addition to its cost-effective advantage, $\mathrm{HCl}$ had been widely applied in sandstone stimulation. However, $\mathrm{HCl}$ is also highly corrosive and hazardous to the well, especially in high-temperature, high-pressure (HTHP) formation environment (Van Domelen and Jennings 1995). Therefore in the future research, the disadvantages of mud acid must be carefully taken into consideration. A summarized classification of the reviewed experimental works using mud acid is presented in Table 7.
Table 6 Summary of core flow test results in Jauf and Berea cores (Thomas et al. 2002b)

\begin{tabular}{|c|c|c|c|c|c|}
\hline Type of core & Core no. & $\begin{array}{l}\text { Treatment: } \\
\text { (1) Pre-flush } \\
\text { (2) Main fluid } \\
\text { (3) Overflush }\end{array}$ & $\begin{array}{l}\text { Initial perme- } \\
\text { ability (mD) }\end{array}$ & $\begin{array}{l}\text { Final perme- } \\
\text { ability (mD) }\end{array}$ & $\begin{array}{l}\text { Final/original } \\
\text { permeability } \\
\text { ratio }\end{array}$ \\
\hline Jauf & 774 & $\begin{array}{l}\text { (1) } 10 \mathrm{wt} \% \text { acetic acid } \\
\text { (2) } 4 \mathrm{wt} \% \mathrm{HCl}-1 \mathrm{wt} \% \mathrm{HF} \\
\text { (3) } 6 \mathrm{wt} \% \mathrm{NH}_{4} \mathrm{Cl}\end{array}$ & 22.7 & 43.4 & 1.9 \\
\hline Jauf & 777 & $\begin{array}{l}\text { (1) } 10 \mathrm{wt} \% \text { acetic acid } \\
\text { (2) } 9 \mathrm{wt} \% \mathrm{HCl}-1 \mathrm{wt} \% \mathrm{HF} \\
\text { (3) } 6 \mathrm{wt} \% \mathrm{NH}_{4} \mathrm{Cl}\end{array}$ & 18.7 & 180 & 9.6 \\
\hline Jauf & 778 & $\begin{array}{l}\text { (1) } 10 \mathrm{wt} \% \text { acetic acid } \\
\text { (2) } 12 \mathrm{wt} \% \mathrm{HCl}-3 \mathrm{wt} \% \mathrm{HF} \\
\text { (3) } 6 \mathrm{wt} \% \mathrm{NH}_{4} \mathrm{Cl}\end{array}$ & 8.5 & 195 & 22.9 \\
\hline Berea & 1 & $\begin{array}{l}\text { (1) } 10 \mathrm{wt} \% \text { acetic acid } \\
\text { (2) } 9 \mathrm{wt} \% \mathrm{HCl}-1 \mathrm{wt} \% \mathrm{HF} \\
\text { (3) } 6 \mathrm{wt} \% \mathrm{NH}_{4} \mathrm{Cl}\end{array}$ & 73 & 105 & 1.4 \\
\hline Berea & 2 & $\begin{array}{l}\text { (1) } 10 \mathrm{wt} \% \text { acetic acid } \\
\text { (2) } 12 \mathrm{wt} \% \mathrm{HCl}-3 \mathrm{wt} \% \mathrm{HF} \\
\text { (3) } 6 \mathrm{wt} \% \mathrm{NH}_{4} \mathrm{Cl}\end{array}$ & 87 & 264 & 3.0 \\
\hline Berea & 7 & $\begin{array}{l}\text { (1) } 10 \mathrm{wt} \% \text { acetic acid } \\
\text { (2) } 4 \mathrm{wt} \% \mathrm{HCl}-1 \mathrm{wt} \% \mathrm{HF} \\
\text { (3) } 6 \mathrm{wt} \% \mathrm{NH}_{4} \mathrm{Cl}\end{array}$ & 81 & 129 & 1.6 \\
\hline
\end{tabular}

إي مدينة الملك عبدالعزيز

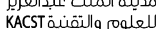


Fig. 7 Optimum HF concentration based on mineral content determined by Abdelmoneim and Nasr-El-Din (2015)

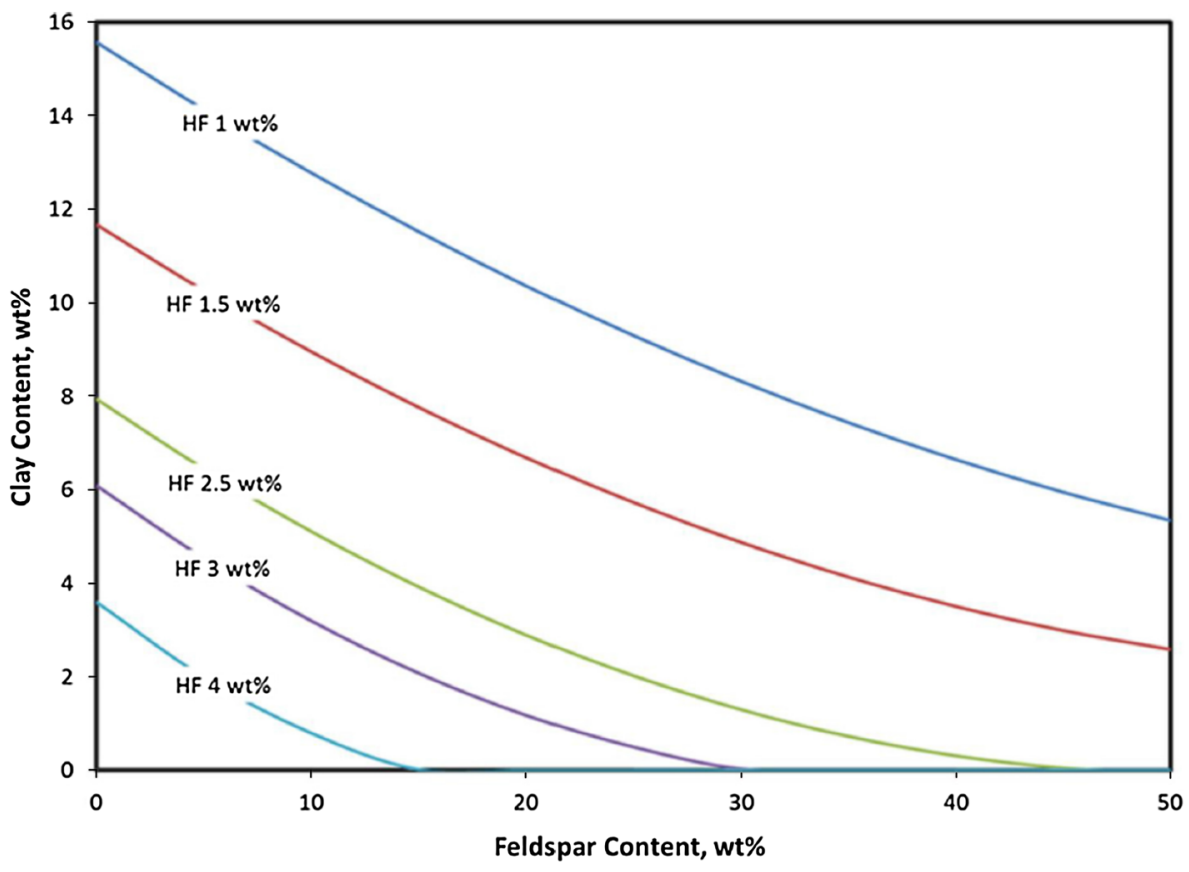

\section{Fluoroboric acid $\left(\mathrm{HBF}_{4}\right)$}

Mcbride et al. (1979) and Thomas and Crowe (1981) demonstrated the application of fluoroboric acid in different case studies. $\mathrm{HBF}_{4}$ generates $\mathrm{HF}$ at a slower rate; therefore, allowing more time for the acid to penetrate into the sandstone. Fluoroboric acid will hydrolyze in aqueous solution to form hydrofluoric acid until it reaches a limit extent, as shown in the following equations:

$$
\begin{aligned}
& \mathrm{HBF}_{4}+\mathrm{H}_{2} \mathrm{O} \rightarrow \mathrm{HBF}_{3} \mathrm{OH}+\mathrm{HF} \text { (slow) } \\
& \mathrm{HBF}_{3} \mathrm{OH}+\mathrm{H}_{2} \mathrm{O} \rightarrow \mathrm{HBF}_{2}(\mathrm{OH})_{2}+\mathrm{HF} \text { (rapid) } \\
& \mathrm{HBF}_{2}(\mathrm{OH})_{2}+\mathrm{H}_{2} \mathrm{O} \rightarrow \mathrm{HBF}(\mathrm{OH})_{3}+\mathrm{HF} \quad \text { (rapid) }
\end{aligned}
$$

$\mathrm{HBF}(\mathrm{OH})_{3}+\mathrm{H}_{2} \mathrm{O} \rightarrow \mathrm{H}_{3} \mathrm{BO}_{3}+\mathrm{HF} \quad$ (rapid).

$\mathrm{HBF}_{4}$ is also useful in removing formation damage as well as stabilizing clays and other fines (Thomas and Crowe 1978, 1981; Svendsen et al. 1992). However, the retardation of $\mathrm{HBF}_{4}$ becomes less significant when the temperature increases to $150^{\circ} \mathrm{F}$. Kunze and Shaughnessy (1983) showed that hydrolysis of $\mathrm{HBF}_{4}$ in water to form $\mathrm{HF}$ accelerated when the temperature increased.

Ayorinde et al. (1992) showed the advantage of $\mathrm{HBF}_{4}$ in treating a Nigerian oil well that faced severe fines migrationrelated issues created by conventional mud acid. $\mathrm{HBF}_{4}$ had proven its compatibility in stabilizing fines migration. After being acidized with mud acid, the production of the oil well is 850 barrels liquid per day (BLPD). However, due to fines migration, the production declined to nearly zero. After successful $\mathrm{HBF}_{4}$ treatment, the production increased to 2500 BLPD and maintained 220 barrel oil per day (BOPD) oil production even after 1 year. Figure 8 shows the production improvement in the Nigerian oil well.

Figure 9 demonstrates the scanning electron microscope (SEM) results of pore filling clay before and after treatment with conventional mud acid and fluoroboric acid, respectively. It was clear from the figure in the lower left that clays were dissolved, while the lower right shows partially fused kaolinite platelets. This had prevented the issue of fines migration (Ayorinde et al. 1992).

Jaramillo et al. (2010) further developed the use of $\mathrm{HBF}_{4}$ acid in sandstone acidizing by mixing organic acid and $\mathrm{HBF}_{4}$ to form a new acid system named as organic clay acid (OCA). Many wells had been stimulated using OCA and treated in low-temperature reservoirs at below $140{ }^{\circ} \mathrm{F}$. The real field results proved the effectiveness of OCA in fines control and clay stabilization. In comparison with the initial production increase of the wells treated with an organic mud acid, it had been observed that higher initial production increase happened on the wells stimulated with OCA. This indicated that OCA had successfully mitigated the issue of fines migration caused by organic mud acid.

In addition, Feng et al. (2011) carried out an investigation on a high-temperature deep penetrating (HTDP) acid. In this research, a mixture of complex organo-phosphatehydrolyzed fluoride salts was developed as a new corrosion inhibitor. It could generate HF and, therefore, make HTDP acid compatible at high-temperature formations. HTDP acid was determined to have a much higher solubility for 
Table 7 Summarized interpretation of reviewed papers on mud acid used in matrix acidizing

\begin{tabular}{|c|c|c|c|c|c|c|c|}
\hline References & Methodology & Approach & Analysis & Rock type & Acid system & Condition & Remarks \\
\hline $\begin{array}{l}\text { Thomas et al. (2001, } \\
\text { 2002a, 2002b) }\end{array}$ & Experimental & Core flooding & $\begin{array}{l}\text { XRD } \\
\text { SEM } \\
\text { Thin section }\end{array}$ & $\begin{array}{l}\text { Berea sandstone } \\
\text { Jauf sandstone }\end{array}$ & Mud acid & $300^{\circ} \mathrm{F}$ & $\begin{array}{l}\text { Mud acid ratio of } 12: 3 \text {, } \\
\text { 9:1 and } 4: 1 \text { yield } \\
\text { different reaction } \\
\text { products }\end{array}$ \\
\hline Nevito Gomez (2006) & Experimental & Core flooding & CT scan & $\begin{array}{l}\text { Berea sandstone } \\
\text { Cream chalk Carbon- } \\
\text { ate } \\
\text { Indiana limestone }\end{array}$ & Mud acid & $\begin{array}{l}72^{\circ} \mathrm{F} \\
100^{\circ} \mathrm{F}\end{array}$ & $\begin{array}{l}\text { The higher the flow } \\
\text { rate, the higher the } \\
\text { permeability change } \\
\text { at room temperature } \\
\text { Optimum flow rate is } \\
\text { determined at } 30 \mathrm{ml} / \\
\text { min for Berea sand- } \\
\text { stone at } 100^{\circ} \mathrm{F}\end{array}$ \\
\hline $\begin{array}{l}\text { Gomaa et al. (2013) \& } \\
\text { Wang et al. (2013) }\end{array}$ & Experimental & Core flooding & XRD & $\begin{array}{l}\text { Berea sandstone } \\
\text { Bandera sandstone }\end{array}$ & Mud acid & $180^{\circ} \mathrm{F}$ & $\begin{array}{l}\text { Single-stage mud } \\
\text { acid ratio of } 15: 1.9 \text {, } \\
10: 2.3,5: 2.6 \text { and } \\
3: 2.8 \text { improved the } \\
\text { permeability of Ban- } \\
\text { dera sandstone } \\
\text { A pre-flush using } \mathrm{HCl} \\
\text { is needed }\end{array}$ \\
\hline $\begin{array}{l}\text { Abdelmoneim and } \\
\text { Nasr-El-Din (2015) }\end{array}$ & Experimental & Core flooding & ICP & $\begin{array}{l}\text { Berea sandstone } \\
\text { Bandera sandstone }\end{array}$ & Mud acid & $\begin{array}{l}280^{\circ} \mathrm{F} \\
325^{\circ} \mathrm{F}\end{array}$ & $\begin{array}{l}\text { The best } \mathrm{HF} \text { concen- } \\
\text { tration is } 1 \mathrm{wt} \% \text { for } \\
\text { Bandera sandstone } \\
\text { and } 1.5 \mathrm{wt} \% \text { for } \\
\text { Berea sandstone } \\
\text { Retarded acids are } \\
\text { recommended for } \\
\text { high-temperature } \\
\text { sandstone condition } \\
\text { at } 300{ }^{\circ} \mathrm{F}\end{array}$ \\
\hline $\begin{array}{l}\text { Al-Harthy et al. } \\
\text { (2009) }\end{array}$ & Review & N/A & N/A & N/A & Mud acid & $200^{\circ} \mathrm{F}$ & $\begin{array}{l}\text { The use of mud acid at } \\
\text { high temperature of } \\
200^{\circ} \mathrm{F} \text { leads to rapid } \\
\text { reaction rate and early } \\
\text { acid consumption }\end{array}$ \\
\hline
\end{tabular}

Fig. 8 The production improvement in the Nigerian oil well (Ayorinde et al. 1992)

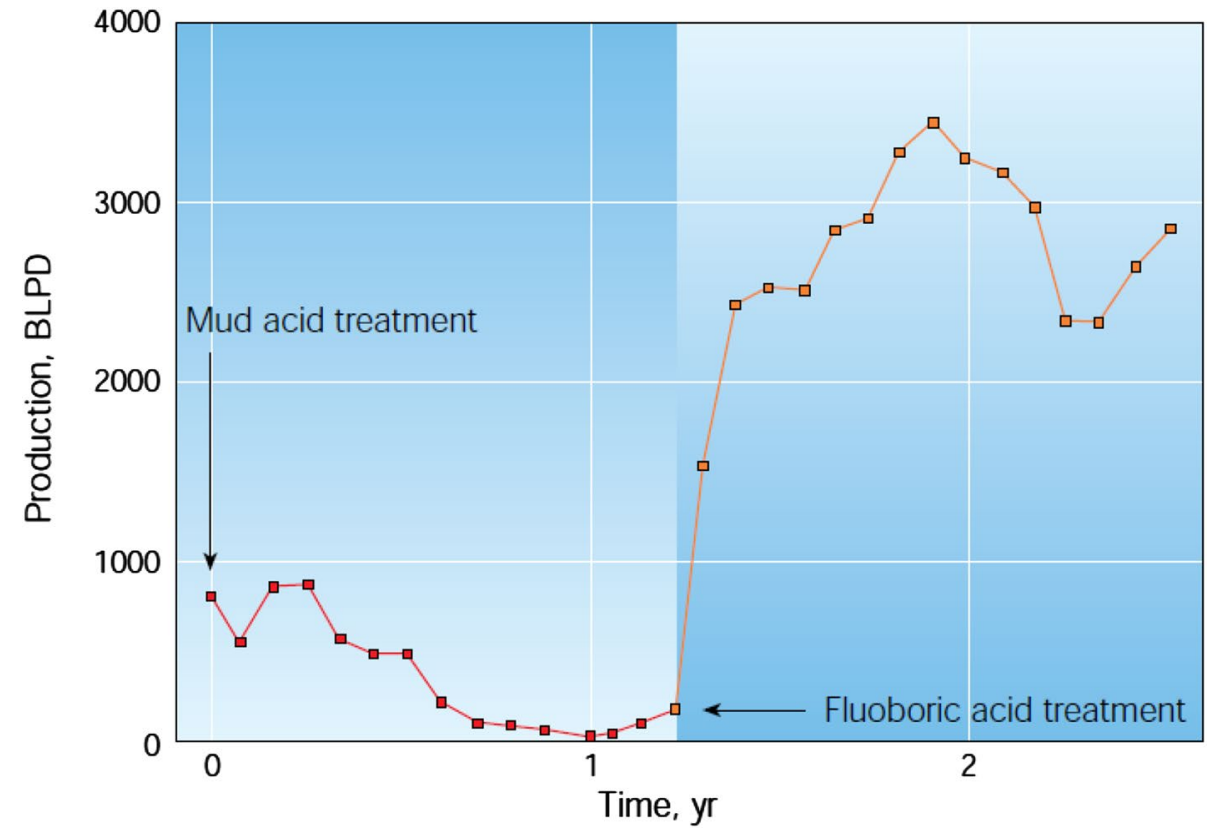


Fig. 9 Comparison of SEM results showing pore filling clay before and after treatment with mud acid and fluoroboric acid (Crowe et al. 1992)
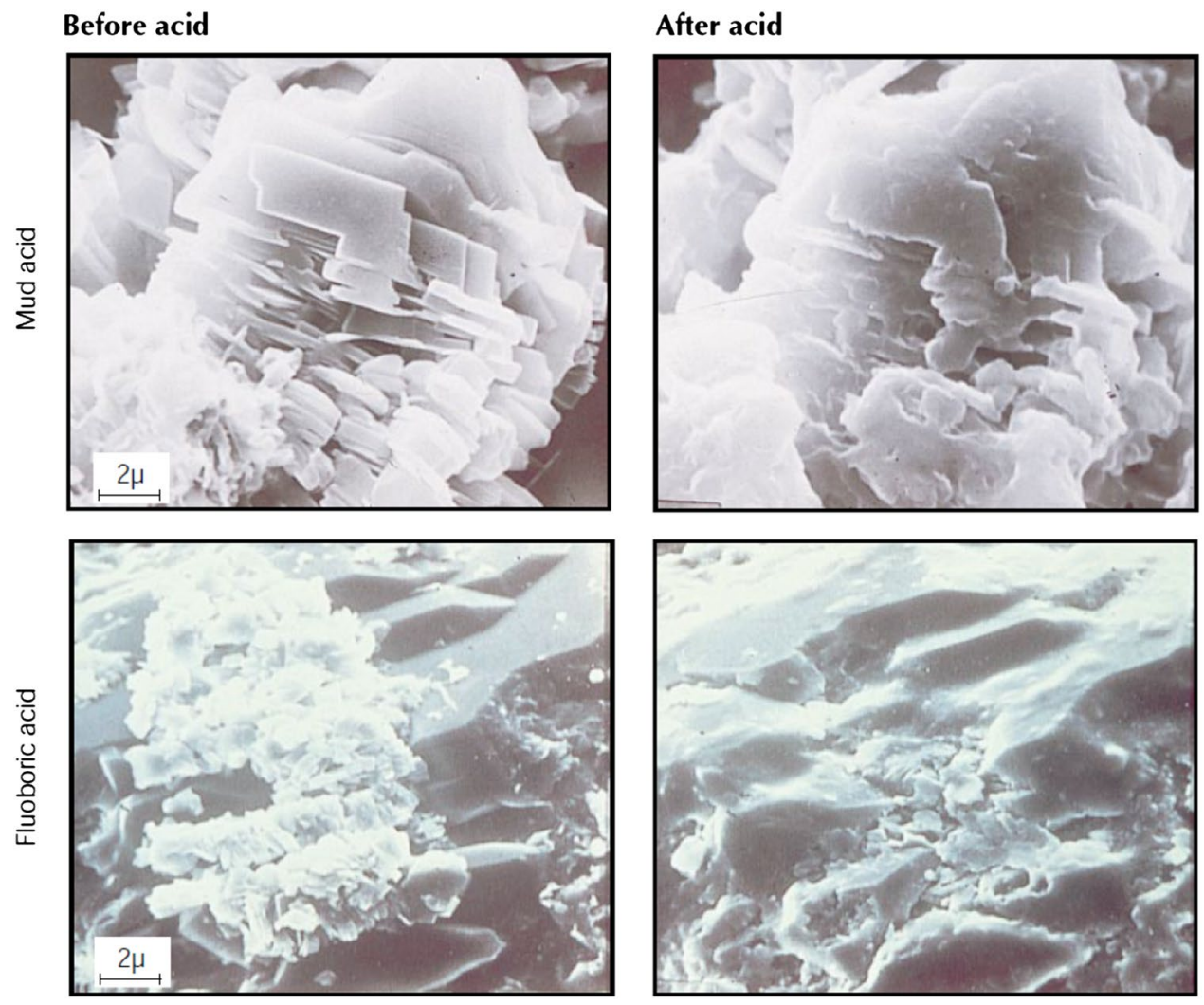

quartz mineral than mud acid and it will also cut back the precipitation. HTDP acid is also better than $\mathrm{HBF}_{4}$ in terms of permeability enhancement.

Pituckchon (2014) investigated the chemistry of $\mathrm{HBF}_{4}$ for better understanding of its stimulation application in real field. ${ }^{11} \mathrm{~B}$ and ${ }^{19} \mathrm{~F}$ solution-state high-field nuclear magnetic resonance (NMR) is applied to analyze the spent acid during the core flooding test over an interval of time. The core flooding experiments were conducted at 75 and $200{ }^{\circ} \mathrm{F}$ to determine the effect of temperature on the compatibility of $\mathrm{HBF}_{4}$. The results showed a reduction in core permeability at $200{ }^{\circ} \mathrm{F}$ due to the precipitation of amorphous silica.

Zhou et al. (2016) also performed core flooding experiments using $12 \% \mathrm{HBF}_{4}$ combined with $12 \% \mathrm{HCl}$ at 25 and $65{ }^{\circ} \mathrm{C}$. The results were compared to conventional $3 \% \mathrm{HF}$ and $12 \% \mathrm{HCl}$. The results indicated that the permeability enhancement reflected by the fluoroboric acid combination is $40 \%$ higher than the conventional mud acid. Also, permeability enhancement is greater at $65^{\circ} \mathrm{C}$ than $25^{\circ} \mathrm{C}$. The work done by Zhou et al. (2016) only compared two temperatures, which are 25 and $65^{\circ} \mathrm{C}$. There is no optimization work being conducted and, therefore, the optimum temperature range for the recommended use of $\mathrm{HBF}_{4}$ remains undetermined. In addition, the core sample used is a heterogeneous sandstone, with $9 \%$ being clay and calcite. An evaluation of the homogeneous clean sandstone is also recommended in the future.
A summary of classification on the reviewed experimental works using $\mathrm{HBF}_{4}$ is interpreted in Table 8.

\section{Chelating agents}

Frenier et al. (2004) developed chelant based on hydroxethylaminocarboxylic acid (HACA) and tested it on Berea sandstone. The results revealed that this HACA chelant can be used for high-temperature sandstone reservoir. The benefits of this chelant included reduced corrosion rate, reaction rate and close to neutral $\mathrm{pH}$ value. HACA acts as a corrosion inhibitor to form insoluble surface chelates. It also features a low reaction rate with dolomite. Also, the near-neutral $\mathrm{pH}$ value of HACA would eliminate the need for fluid treatment before disposal. Therefore, this chelant had advantages considering aspects of health, safety and environment (HSE) due to lower HSE footprint. Tuedor et al. (2006) also used a newly developed sandstone stimulating system, which was a chelant-based system, resulting in not only effective acidizing at $200-300^{\circ} \mathrm{F}$, but also less corrosive, safer to handle and lower HSE footprint.

In addition, Ali et al. (2008) had studied the effect of sodium hydroxyethylethylenediaminetriacetic acid ( $\mathrm{Na}_{3}$ HEDTA), which is a low-pH solution to stimulate a high-temperature formation in West Africa using experimental approach. The result indicated that the chelating fluid is efficient in increasing the permeability of the

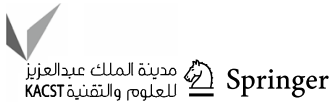




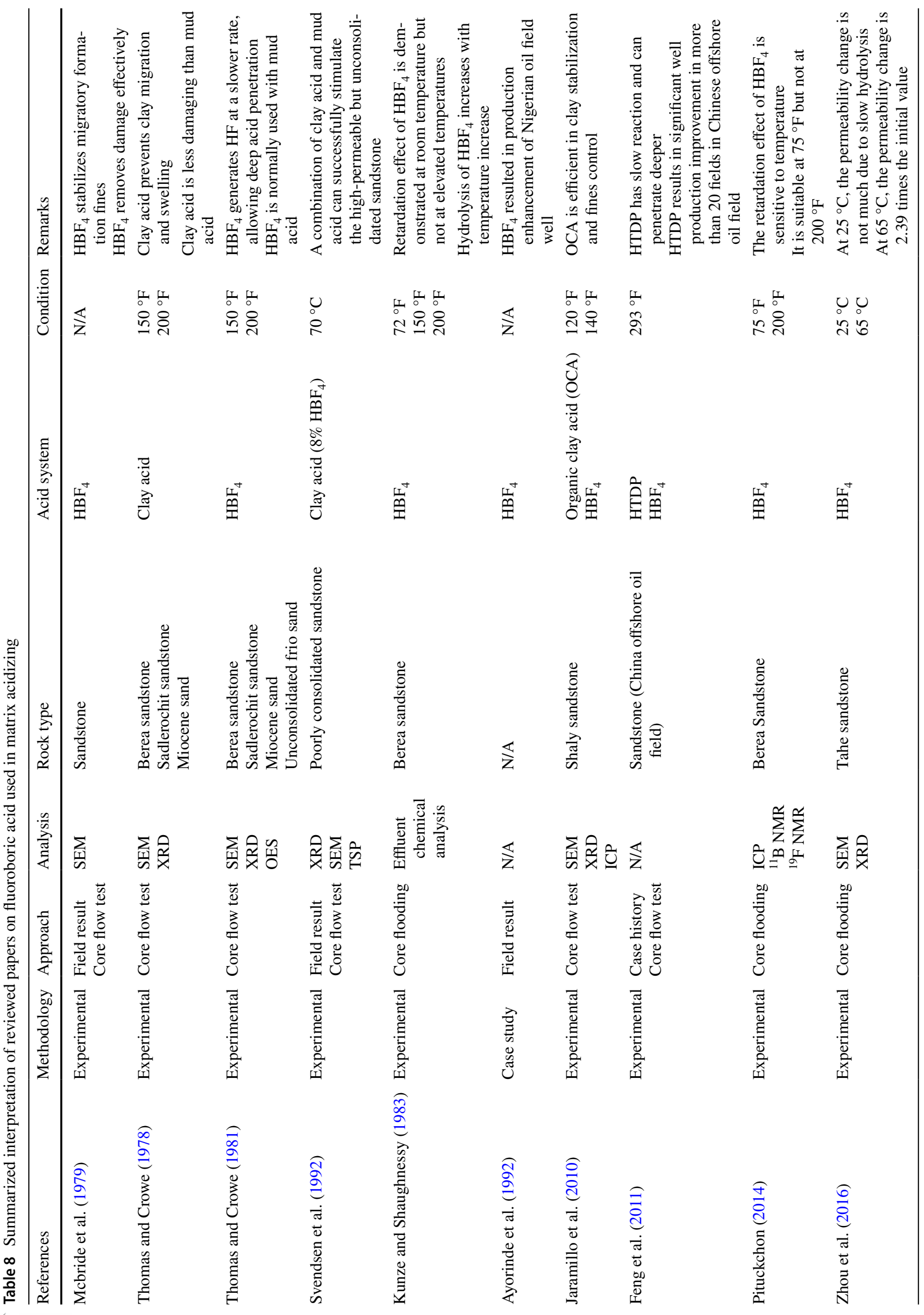


high-temperature well. Moreover, Parkinson et al. (2010) also applied an alternative approach to stimulate the production zone of Pinda formation that is located in West Africa. The Pinda formation was having multilayers of carbonates. The bottomhole static temperature (BHST) of this formation was $300{ }^{\circ} \mathrm{F}$. The six production wells from the formation zone were being stimulated with a $\mathrm{pH} 4$ HEDTA chelant during the main flush stage. The result showed that all the six wells are then producing at a doubled rate after the stimulation, indicating a high economical return resulted from the stimulation acid at a high temperature.

LePage et al. (2009) investigated the reaction between glutamic acid $N, N$-diacetic acid (GLDA) and calcites in carbonate rock. GLDA had been compared to many other chelants such as ethylenediaminetetraacetic acid (EDTA), hydroxyethylethylenediaminetriacetic acid (HEDTA), nitrilotriacetic acid (NTA) and ethanol diglycine acid (EDG). In the discussion, the efficiency of GLDA is the same as HEDTA although it is not as corrosive as $\mathrm{HCl}$. Aside from that, GLDA was also used by Mahmoud et al. (2011) to study its effect on stimulating sandstone formations. The research focused on multiple parameters, including temperature, rate of injection, volume and initial $\mathrm{pH}$ value of GLDA. The results clearly revealed the powerful capability of GLDA to chelate calcium, iron and magnesium. Besides, GLDA was found to chelate even small amounts of aluminum ions in the sandstone cores (Mahmoud et al. 2011). Moreover, the concentration of GLDA was found to be almost the same prior to and after core flooding test. GLDA also demonstrated a high thermal stability at $300^{\circ} \mathrm{F}$ and potentially lower corrosion properties. This was further proven by Nasr-El-Din (2013). According to the result, GLDA increased the core permeability of $21 \%$ at $200{ }^{\circ} \mathrm{F}$ and $84 \%$ at $300{ }^{\circ} \mathrm{F}$, respectively, whereas, on the opposite side, $\mathrm{HCl}$ resulted in the precipitation of iron hydroxide, $\mathrm{Fe}(\mathrm{OH})_{2}$, causing a $42 \%$ permeability reduction.

Furthermore, Reyes et al. (2015) used a low $2.5 \mathrm{pH}$ GLDA chelant to experimentally investigate its stimulation on high-quartz clean sandstone matrix and high-clay heterogeneous sandstone matrix. The results reflected a $20 \%$ permeability decrease for the clean sandstone but a $30 \%$ permeability increase for the heterogeneous sandstone. This indicated that this GLDA/HF chelant is more suitable for sandstone with clay content, but not clean sandstone.

Another chelant-based fluid system was tested by Rignol et al. (2015) to stimulate sandstone core at $375^{\circ} \mathrm{F}$, which is an ultrahigh-temperature environment. This acid system was a combination of low-pH chelant and fluroboric acid, $\mathrm{HBF}_{4}$. The core plugs were experimented with flow test and some chemical analyses. Based on the sequential dissolution analyses, the results showed that the chelant-based fluid did not cause silica precipitation as $\mathrm{HCl}$ is absent. Furthermore, it had increased the permeability of the core effectively. Garcia et al. (2016) had revealed the advantages of aminopolycarboxylic acid (APCA) fluid that contained $1-1.5 \%$ of HF. This fluid system is better than the conventional mud acid that is inefficient to stimulate high-temperature sandstone condition above $300^{\circ} \mathrm{F}$ due to the precipitation of sodium and potassium iron. The application of APCA/HF* blend fluid system in offshore reservoirs was a success, resulting in 30-50\% barrel oil per day production improvement for more than a period of 12 months.

Legemah et al. (2015) proposed a two-step injection process using chelating agents to treat high-temperature wells. First, the author suggested injection of low-volume but highconcentration APC, then followed by injection of high-volume but low-concentration APC such as GLDA. Mahmoud et al. (2015) examined the carbonate removal compatibility of GLDA, HEDTA and $15 \mathrm{wt} \% \mathrm{HCl}$ using illitic sandstone core at high temperature of $300{ }^{\circ} \mathrm{F}$. The outcomes of the core flooding experiment revealed that $\mathrm{HCl}$ is not compatible to remove carbonates in illitic sandstone, but results in reduced porosity and permeability, which damaged the sandstone matrix. On the other hand, both GLDA and HEDTA demonstrated high efficiency in carbonate mineral removal.

Based on the earlier literature review, many experiments using chelating agents were conducted and reported by past researchers. These chelants could be applied to stimulate high-temperature well. The efforts of these past studies, focusing on the effectiveness of chelants at high-temperature condition, were highly appreciated. It was proven that these acid systems were suitable and reliable to gain extensively wide application in real-field practice. However, it should also be alerted that chelating agents are generally less suitable for clean homogeneous sandstones because of the silica precipitation during acidizing. Therefore, they are more suitable for heterogeneous carbonates and clay-rich sandstones. Another point of view that should be noticed is that chelants are very costly products as compared to mud acid, retarded acid and organic acids. Although chelating agents can reduce the cost of corrosion inhibitor used, it is still important to optimize the budget between the costly chelants and corrosion inhibitor. A summary of classification on the reviewed experimental works using chelating agents is presented in Table 9.

\section{Retarded acids and organic acids}

Addition of retarding agent into conventional mud acid formed another study to solve the problem associated with the reaction of acids and the clay minerals. According to the investigation by Ji et al. (2014) and Ji et al. (2016), aluminum chloride, $\mathrm{AlCl}_{3}$ was added to conventional mud acid to form retarded mud acid. It was also known as fines control acid, which is comprised of $15 \% \mathrm{HCl}, 1.5 \% \mathrm{HF}$ and $5 \%$ $\mathrm{AlCl}_{3} \cdot 6 \mathrm{H}_{2} \mathrm{O}$. The experiment was carried out on Berea core

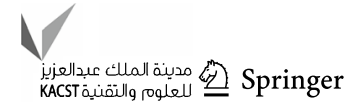




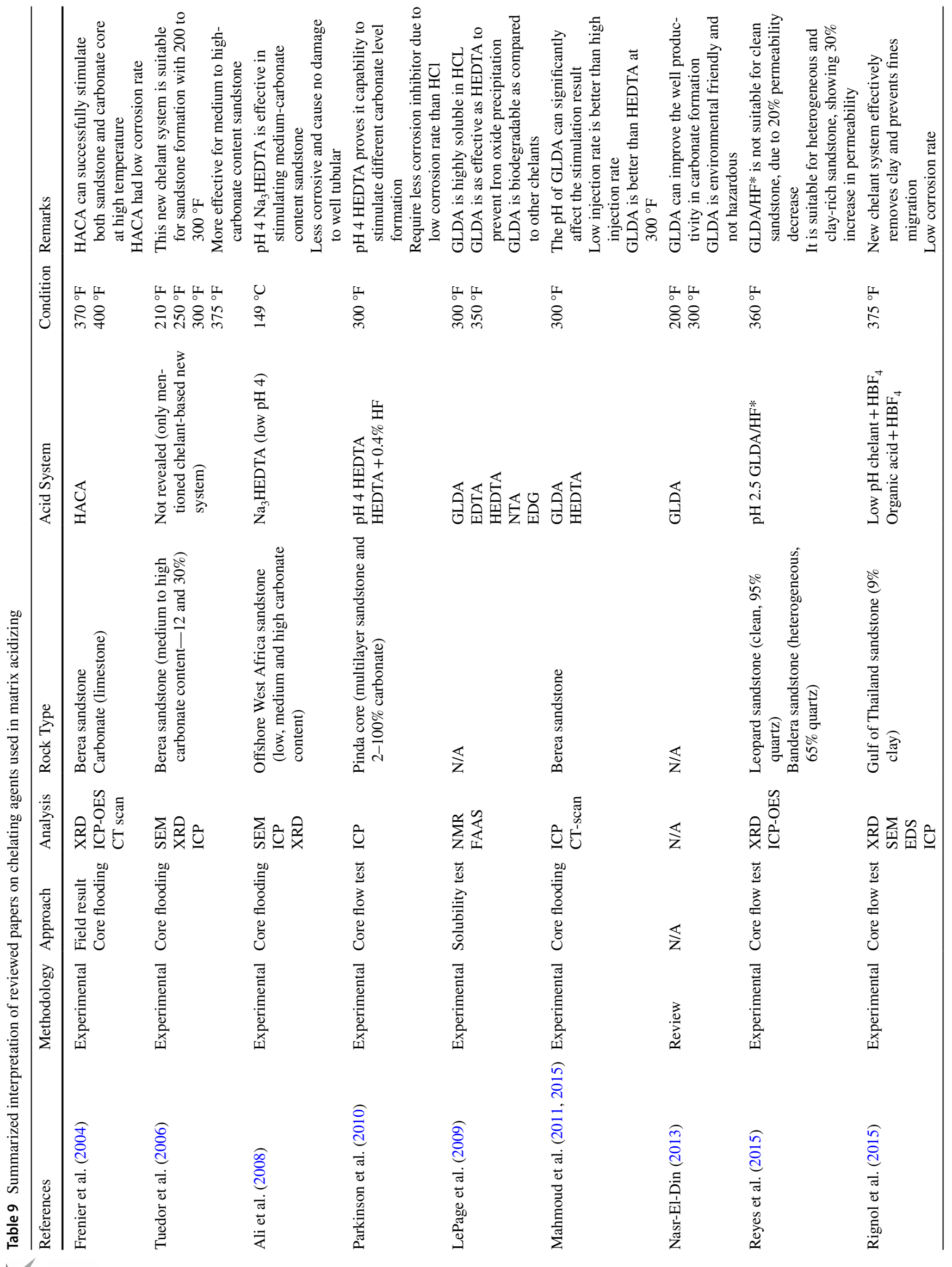


samples at both 75 and $200{ }^{\circ} \mathrm{F}$. Based on the solubility test result, no $\mathrm{AlF}_{3}$ precipitate was detected at both temperatures. Aneto (2012) also conducted core flooding tests and compared the use of retarded mud acid using $\mathrm{AlCl}_{3}$. The result showed a reduction in rate of reaction by the retarded acid, allowing deeper acid penetration and better damage removal.

In the earlier years, organic acids such as acetic and formic acid; and powdered acid such as sulfamic and chloroacetic acid were developed by researchers (Farley et al. 1970; Wehunt et al. 1993; Shuchart and Gdanski 1996; Shuchart 1997). For instance, Templeton et al. (1975) discovered a new approach to retard the consumption rate of HF acid using methyl formate to generate formic acid, $\mathrm{CH}_{3} \mathrm{COOH}$. Then, $\mathrm{HF}$ is generated at a controllable rate by adding ammonium fluoride, $\mathrm{NH}_{4} \mathrm{~F}$. In general, methyl formate hydrolyzes slowly to produce HF. The reaction equations to form HF were described as follows:

$$
\begin{aligned}
& \mathrm{HCOOCH}_{3}+\mathrm{H}_{2} \mathrm{O} \rightarrow \mathrm{HCOOH}+\mathrm{CH}_{3} \mathrm{OH} \\
& \mathrm{HCOOH}+\mathrm{NH}_{4} \mathrm{~F} \rightarrow \mathrm{NH}_{4}^{+}+\mathrm{HCOO}^{-}+\mathrm{HF} .
\end{aligned}
$$

Furthermore, Van Domelen and Jennings (1995) applied the use of two organic acids, which are acetic acid $\left(\mathrm{CH}_{3} \mathrm{COOH}\right)$ and formic acid $(\mathrm{HCOOH})$, in stimulating HTHP wells. Both of these organic acids have the favorable properties in sandstone acidizing, included weak ionization and slow reaction. Therefore, these acids cause less corrosion to the well equipment and allow longer reaction period. The acid blend had been applied on Arun limestone formation in Indonesia with high temperature of $350^{\circ} \mathrm{F}$. The well response and corrosion response reflected positively in both technical and economic efficiencies of the acid blend used.

Roger et al. (1998) conducted core flooding on the sandstone core using different formulations of the acid, other than the typical $10 \% \mathrm{HCl}$ and $1.5 \% \mathrm{HF}$. It had been proven that this conventional acid combination caused the formation damage as indicated by $74 \%$ permeability reduction. Based on the results, $10 \%$ citric acid blended with $1.5 \%$ HF was determined to be the optimum acid combination. The production enhancement of 7400 to 16,000 BOPD was observed in five producing wells stimulated using the optimum acid combination.

These organic acids are being further developed as shown in many recent publications. For instance, experimental investigation was conducted by Al-Harbi et al. (2012) using various mixtures of organic-HF acid system in stimulating sandstone cores. The acid combinations included acetic $\left(\mathrm{CH}_{3} \mathrm{COOH}\right)-\mathrm{HF}$, formic $(\mathrm{HCOOH})-\mathrm{HF}$ and citric $\left(\mathrm{C}_{6} \mathrm{H}_{8} \mathrm{O}_{7}\right)-\mathrm{HF}$. The authors study the precipitations that occurred during the acid and rock reactions as well as the factors affecting those precipitations. Based on the results, the precipitate type and amount mainly depend on the $\mathrm{pH}$ of solution, type of organic-HF combination, and initial 
concentration of free fluoride (Al-Harbi et al. 2011). Apart from that, $\mathrm{F} / \mathrm{Al}$ ratio was found to be the main parameter that is associated with the precipitation of aluminum fluoride. The precipitation of aluminum fluoride occurred at a certain point over the critical ratio.

Andotra (2014) evaluated the use of citric acid as a chelating agent and compared the result with conventional mud acid of ratio 9:1. The optimum result was obtained when $1 \mathrm{wt} \%$ citric acid was added into the mud acid. However, the author also mentioned the issue of much higher cost induced by adding citric acid as compared to $\mathrm{HCl}$ and $\mathrm{HF}$. Furthermore, L-glutamic acid $N, N$-diacetic acid, Na-GLDA were combined with $\mathrm{HF}$ and tested using Bandera and Berea cores. The results reflected positively on the chelation of iron $(\mathrm{Fe})$, calcium $(\mathrm{Ca})$ and magnesium $(\mathrm{Mg})$ but not aluminosilicates $\left(\mathrm{Al}_{2} \mathrm{SiO}_{5}\right)$. Nevertheless, the advantages of these chelating agents over $\mathrm{HCl}$ were provided such as lower corrosion, not being sensitive to minerals, being stable at high temperature greater than $200{ }^{\circ} \mathrm{F}$ and also being biodegradable.

Yang et al. (2012a) conducted another experiment using a blend of HF-organic acids instead of mud acid to mitigate the problems associated with mud acid. The authors analyzed the kinetic and products of reactions. The findings of research showed that the type of minerals present in the core plugs has an effect on the reactions (Yang et al. 2012b; Yang 2012). Moreover, Zhou and Nasr-El-Din (2013) studied the efficiency of a single-stage sandstone-acid combination, which is a blend of HF and phosphonic acid during sandstone acid stimulation at $300^{\circ} \mathrm{F}$ high-temperature formation. The authors also evaluated the performance of multiple-acid system to remove carbonate minerals from a sandstone core plug that included a low pH 3.8 GLDA, HEDTA and formic acid, $\mathrm{HCOOH}$. All the acid systems were observed to increase the permeability of Berea sandstone core sample. However, $\mathrm{HCOOH}$ is still more efficient than GLDA and HEDTA in dissolving the carbonate minerals in Bandera sandstone core samples.

Experiments were performed by Shafiq et al. (2013a) to analyze the combination of acetic acid and hydrochloric acid in pre-flush stage. The authors then compare the result with the conventional use of only hydrochloric acid in that stage. The use of acid combination $7.5 \% \mathrm{HCl}+2.5 \% \mathrm{CH}_{3} \mathrm{COOH}$ resulted in $18.5 \%$ porosity enhancement. This proved that the usability of this acid combination is much better to be used as a pre-flush acid than the conventional $10 \% \mathrm{HCl}$, which resulted in only $10.9 \%$ porosity change. At the same time, this research also highlighted the importance of preflush stage in matrix acidizing to dissolve the carbonates to prevent precipitation during the main acid stage.

The research group in recent years led by Shafiq et al. presented multiple experimentations using various acid combinations (Shafiq et al. 2013b, 2014; Shafiq and Shuker 2013;
Shafiq et al. 2015; Shafiq and Ben Mahmud 2016). The acid combinations tested by the authors included a mixture of orthophosphoric $\left(\mathrm{H}_{3} \mathrm{PO}_{4}\right)$ acid and HF; fluoroboric $\left(\mathrm{HBF}_{4}\right)$ acid and $\mathrm{HCOOH}$; and $\mathrm{HCOOH}$ and $\mathrm{HF}$. The methodology applied was core saturation method, whereby the sandstone core plugs are saturated with the mentioned acid combinations. Multiple analyses were carried out to discuss the change in porosity, permeability, mineralogy and strength before and after the experiment. According to their findings, the best acid combination is 3\% HF:9\% $\mathrm{H}_{3} \mathrm{PO}_{4}$. However, all these acid combinations are suitable to be applied as the main acid during sandstone acid stimulation. With $135.32 \%$ increase in permeability, this acid combination is even more superior to the standard mud acid ( $3 \% \mathrm{HF}: 12 \% \mathrm{HCl})$, showing lower increase in permeability, which is $101.76 \%$. Therefore, it was proven that varying the acid combination would result in different outcomes, either in major or minor disparity. However, it should be noted that most of the experimentations were conducted only at ambient or room temperature conditions, which could not represent the real-field environment. Hence, this left a research gap that can be bridged in the future studies.

In addition, a study on the phosphonic-based HF acid system was reported by Zhou and Nasr-El-Din (2016) as an alternate solution to mud acid. The author investigated several parameters affecting the interactions between the new acid systems with the clay minerals such as the concentration of acid, the reaction time and temperature. As shown in the result, phosphonic-based HF acid system resulted in significantly higher enhancement of permeability than mud acid and that was $177.86 \%$ at $300{ }^{\circ} \mathrm{F}$. A summarized classification of the reviewed experimental works using retarded and organic acids is interpreted in Table 10.

\section{Overall characterization and comparison of different acids}

Table 11 shows the positive and cautionary indication of each of the acids reviewed based on the aspects of their feasibility, reaction mechanism as well as cost, health, safety and environmental impact.

\section{Summary of review and outlook}

To sum up the whole literature review, there are numerous acids that had been developed in the past years, aiming to continuously improve the permeability enhancement result, while preventing precipitation. In this study, a detailed evaluation of all these acids are presented as shown in Table 11. Generally, four groups of acids are identified, which include the mud acid (HF), fluoroboric acid $\left(\mathrm{HBF}_{4}\right)$, chelating agents, retarded and organic acids. 


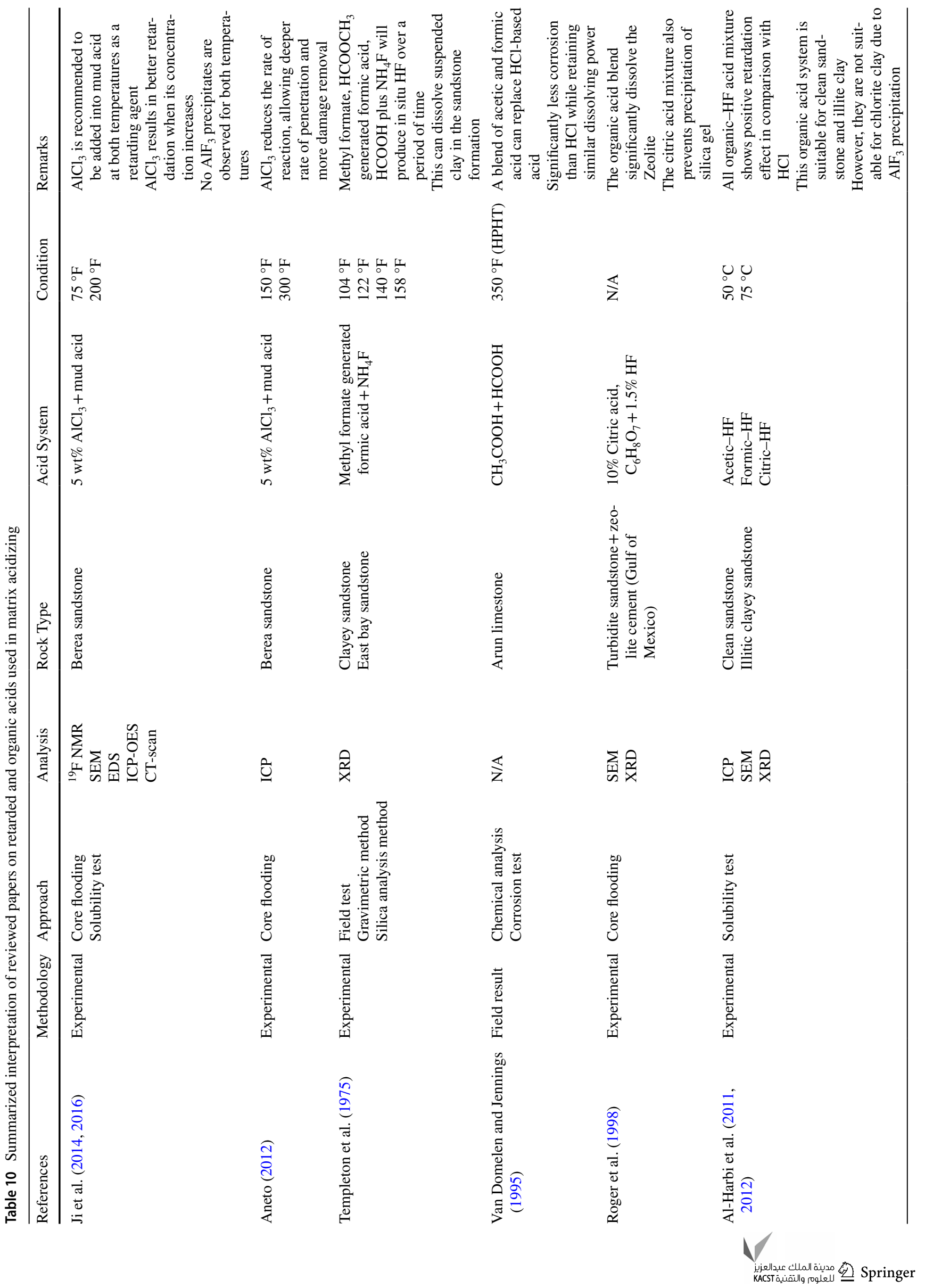




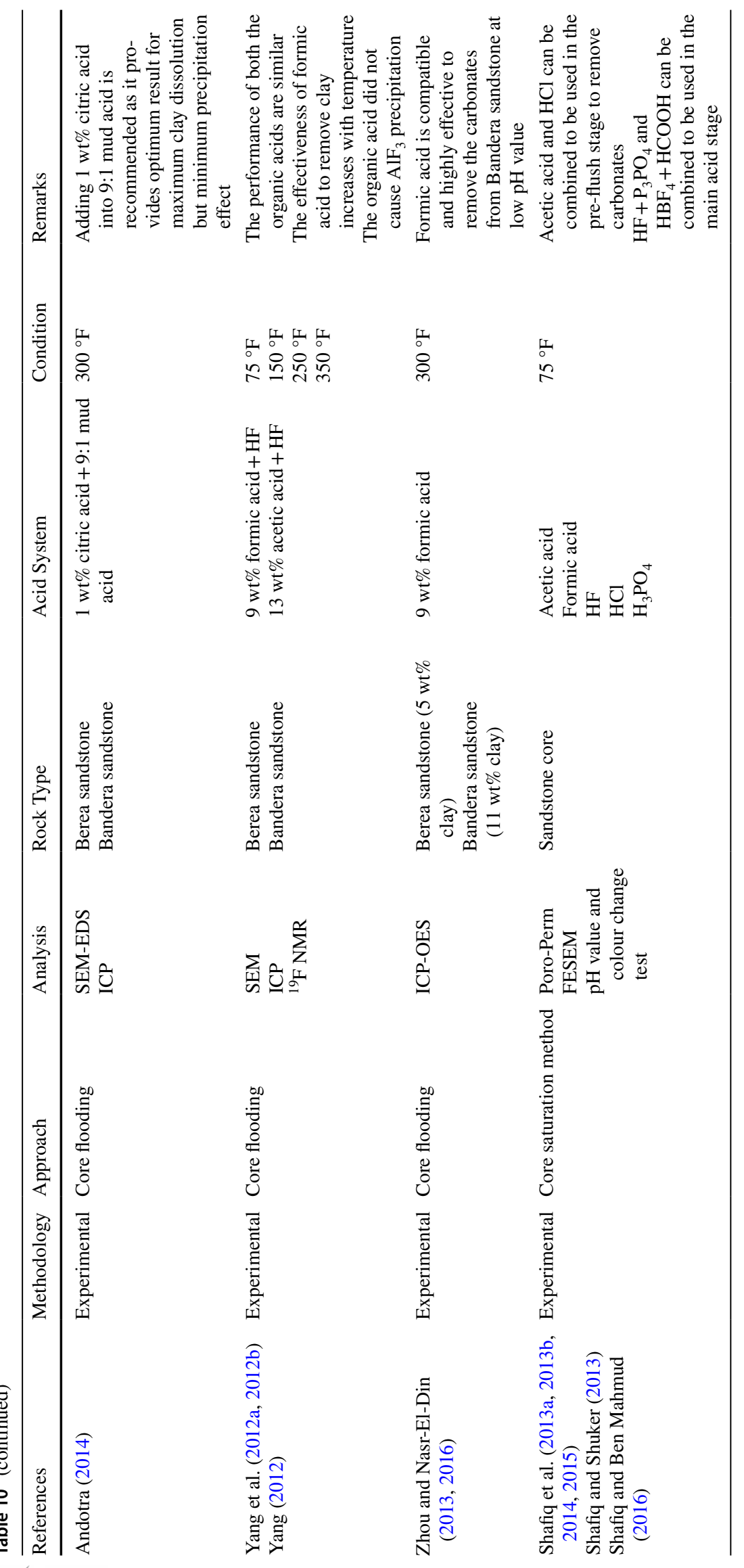




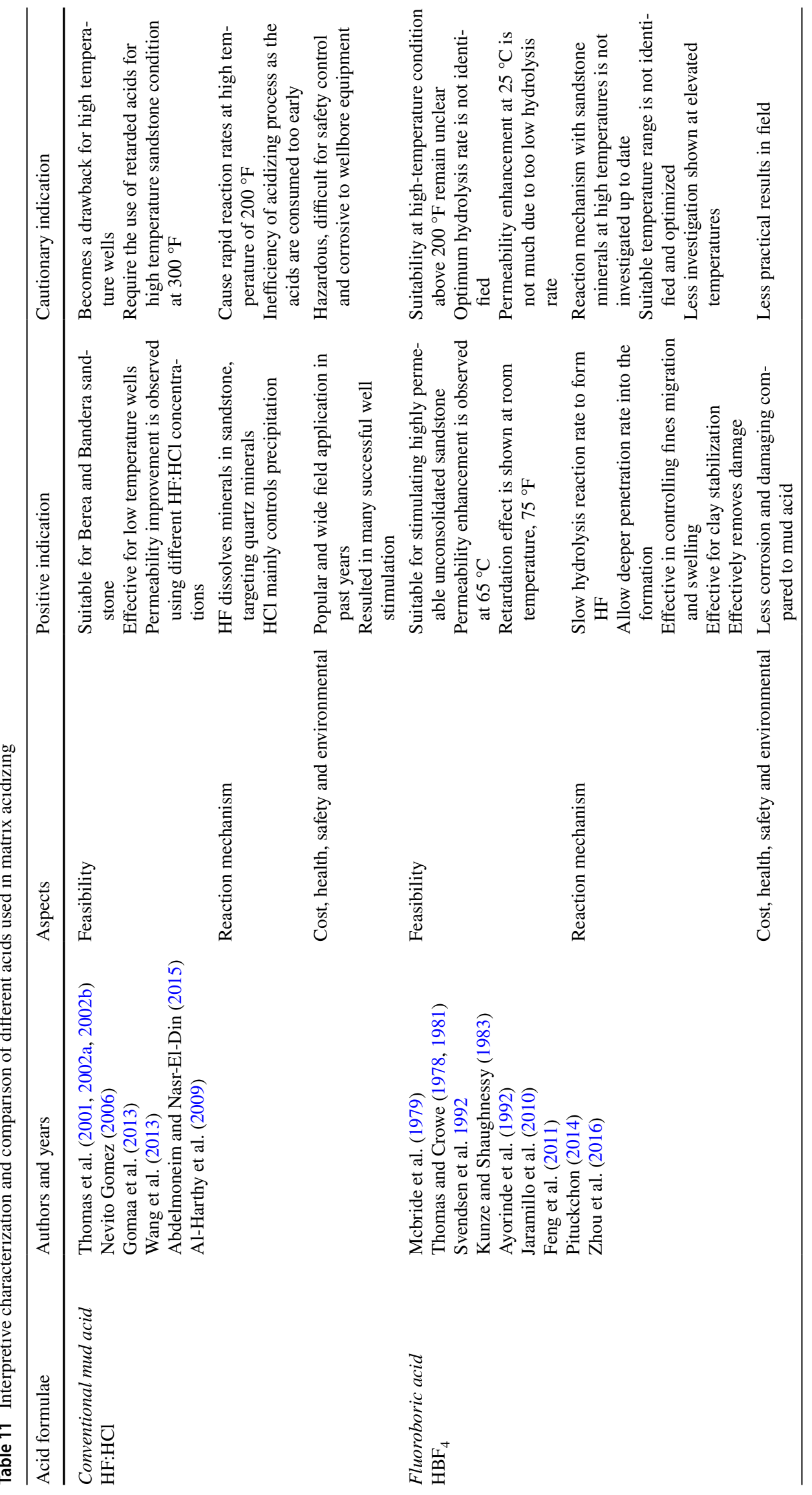




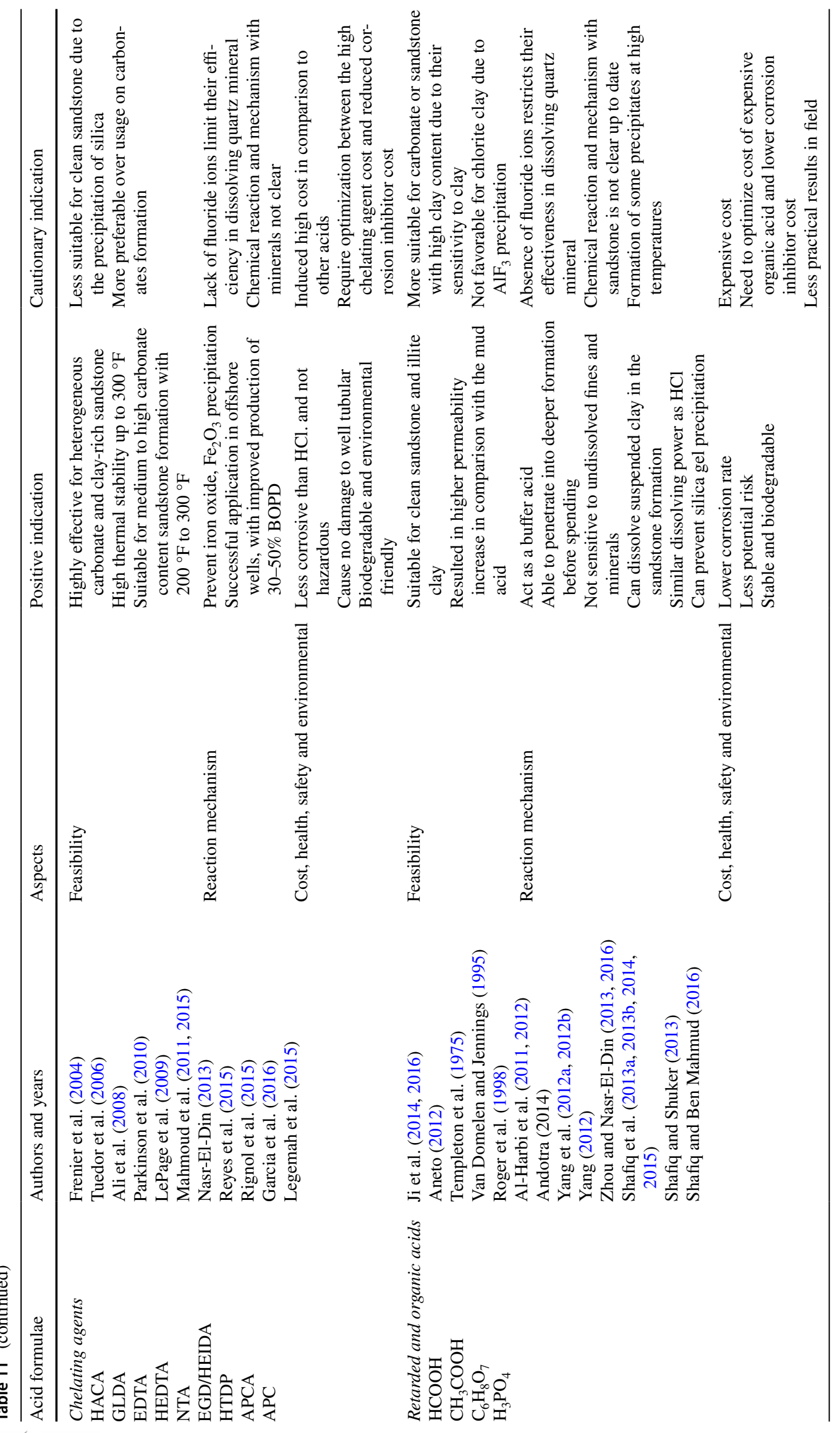

Saئة 
Mud acid is very suitable to stimulate unconsolidated sandstone at low to moderate temperature. It had been commonly applied in sandstone acidizing and had successfully enhanced the porosity and permeability of sandstone formation with quartz mineral content. However, mud acid is not recommended to be used at high-temperature conditions due to rapid rate of reaction with the sandstone mineral, resulting in early acid consumption. Mud acid is also very hazardous and corrosive to the well equipment.

On the other hand, $\mathrm{HBF}_{4}$ is an alternative acid to mud acid at moderate-temperature condition. It is also suitable for unconsolidated sandstone with quartz mineral. However, due to its slow hydrolysis reaction to produce $\mathrm{HF}, \mathrm{HBF}_{4}$ acidizing would result in deeper penetration rate into the sandstone formation. $\mathrm{HBF}_{4}$ is also reported to be effective in fines control, clay stabilization and damage removal. Nevertheless, the literature lacks study on the application of $\mathrm{HBF}_{4}$ at elevated temperature conditions, which is worth further investigation.

Furthermore, chelating agents are effective for heterogeneous carbonate or clay-rich sandstone at very high temperatures. Chelating agents can prevent iron oxide precipitation and is less corrosive. However, it is not recommended for homogeneous clean sandstone because of silica precipitation, which would lower the porosity and permeability. Therefore, the suitability of chelating agents would significantly depend on the mineral contents of the sandstone or carbonates. Finally, the retarded and organic acids are suitable for carbonates or sandstone with high clay content. It is not effective for dissolving quartz content because it lacks of fluoride ions. It also causes some precipitation at hightemperature conditions. Table 12 provides a clear view on the suitable acids for sandstone with high and low quartz content.

\section{Optimization of $\mathrm{HF}$ and $\mathrm{HBF}_{4}$ Sandstone acidizing}

In general, the procedures of experiment and results from these literature studies have provided an important insight and some constructive outlooks for the experimental work or simulation design and setup that are worth technical investigation in the future. As highlighted by Shafiq and Mahmud (2017), the future of matrix acidizing should focus on solving the problems associated with high temperature. New acid combinations developed are expected to not only improve the permeability, but also reduce the precipitation effect.

From a larger perspective, it is clear that there are many different acids that can be technically used in sandstone stimulation besides the mud acid, which is a conventional option and has already been widely applied. These acids that had been used and tested included chelating agents, retarded and organic acid combinations as well as fluoroboric acid. Among all the acids tested by previous researchers, $\mathrm{HBF}_{4}$
Table 12 Alternatives acids for high- and low-quartz content sandstone

\begin{tabular}{ll}
\hline Mineral content & Suitable acid \\
\hline High quartz content & Mud acid \\
& $\mathrm{HF}: \mathrm{HCl}$ \\
& Fluoroboric acid \\
& $\mathrm{HBF}_{4}$ \\
Low quartz content & Chelating agents \\
& $\mathrm{HACA}$ \\
GLDA \\
EDTA \\
HEDTA \\
NTA \\
EGD/HEIDA \\
HTDP \\
APCA \\
APC \\
Organic acids \\
$\mathrm{HCOOH} \mathrm{CH}_{3} \mathrm{COOH}$ \\
$\mathrm{C}_{6} \mathrm{H}_{8} \mathrm{O}_{7}$ \\
Retarded acids \\
$\mathrm{H}_{3} \mathrm{PO}_{4}$ \\
\hline
\end{tabular}

could be further experimented based upon the research conducted by Shafiq and Ben Mahmud (2016) at the higher temperatures of 60,80 and $100{ }^{\circ} \mathrm{C}$. Then, the results could be compared with mud acid under the same temperature conditions.

In view of the shortcoming of the mud acid at high temperatures, $\mathrm{HBF}_{4}$ is foreseen as a better selection in contrast. It is expected to not only improve the porosity and permeability, but also eliminate the previously existing problems as it is less corrosive, stable and allowing deeper penetration due to slow hydrolysis rate. Nevertheless, the limitation of retardation effect of $\mathrm{HBF}_{4}$ remains unknown without detailed optimization approach. More studies are deserved to consolidate the claimed advantages of $\mathrm{HBF}_{4}$ over the mud acid. The key and major parameter affecting the acid stimulation results of $\mathrm{HF}$ and $\mathrm{HBF}_{4}$ must be optimized, along with other parameters such as acid concentration and injection rate.

\section{Proposed experimental work for the future}

Based on the experimental setup of core flooding test as described in the user manual (Sanchez 2016) and procedure described by Nevito Gomez (2006), the steps that are suggested to be adopted to conduct the experimental work in the future are listed as follows. Figure 10 shows the schematic diagram of core flooding test setup schematic diagram.

1. The core flooding apparatus will be set up and calibrated. 


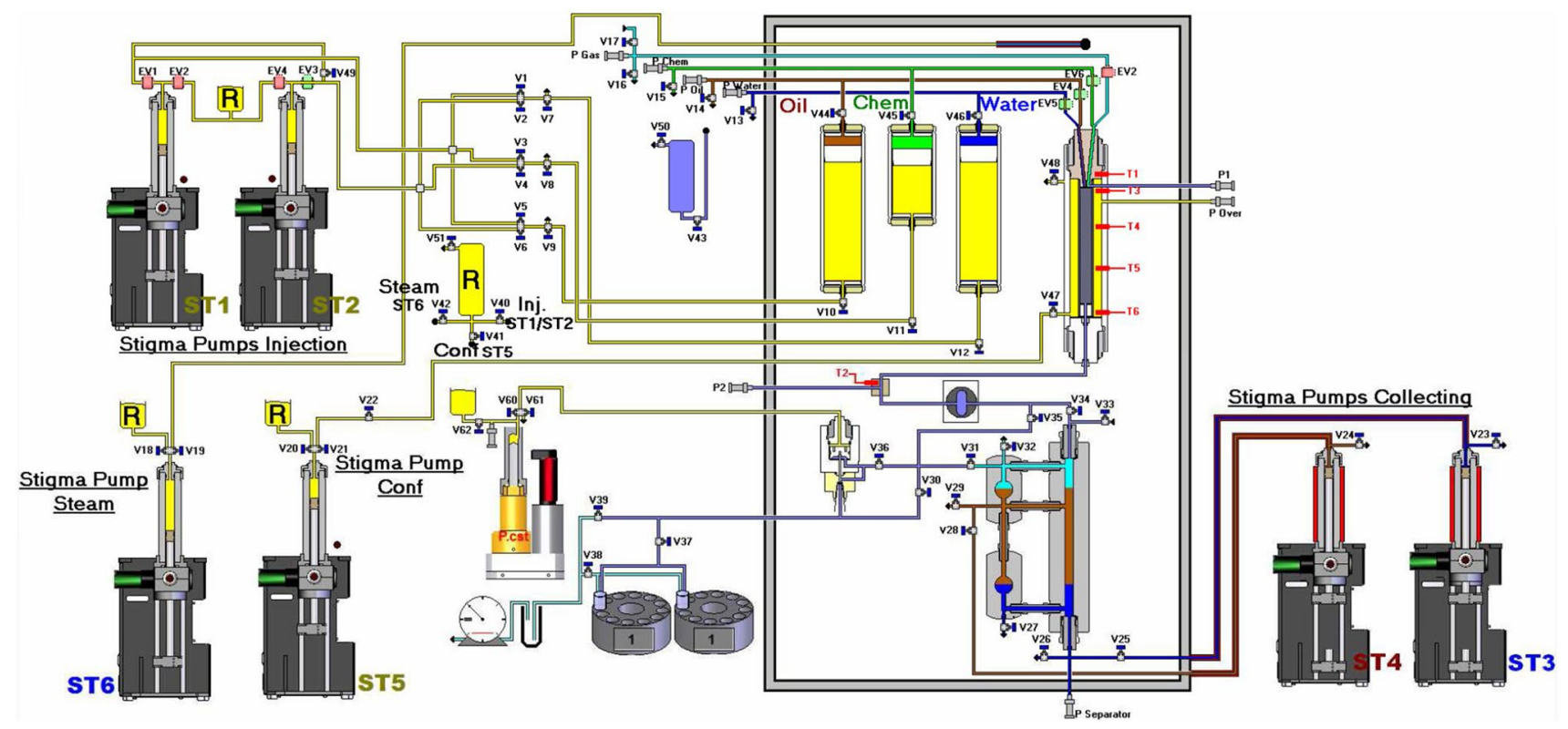

Fig. 10 Core flooding test schematic diagram (Sanchez 2016)

2. The pre-flush, main acid and after-flush acid solutions will be prepared.

3. The initial porosity and permeability will be measured using porosity-permeability (Poro-Perm) apparatus (Shafiq and Ben Mahmud 2016), and the mineralogy will be measured using field emission scanning electron microscope (FESEM) (Shafiq and Ben Mahmud 2016).

4. The core sample will be exposed to brine solution for $2 \mathrm{~h}$ before using core flooding experiment at high operating conditions and a constant flow rate.

5. The pressure variation will be measured during acidizing process and will be turned off when pressure becomes constant.

6. The final sample porosity, permeability and mineralogy will be measured.

7. The reacted acid will be collected and examined for various ions, such as calcium $(\mathrm{Ca})$, magnesium $(\mathrm{Mg})$, iron $(\mathrm{Fe})$, silicon $(\mathrm{Si})$ and aluminum $(\mathrm{Al})$ in solution using inductively coupled plasma (ICP).

8. The data will be collected to study the reaction kinetics and products using F-nuclear magnetic resonance (F-NMR) spectroscopy.

9. The core sample will be scanned using computerized tomography (CT) scan before and after core flooding test to examine depth of acid penetration.

10. The above steps will be repeated for different temperatures of 60,80 and $100{ }^{\circ} \mathrm{C}$.

11. The above steps will be repeated for $\mathrm{HBF}_{4}$ and conventional mud acid (HF) and the results will be compared.
12. Collected data will be used to analyze the reaction mechanism.

\section{Proposed experimental data collection and analyses}

There are a number of experimental tests and analyses that can be performed in the future to characterize the effectiveness of $\mathrm{HF}$ and $\mathrm{HBF}_{4}$ under various conditions, which include

- Poro-Perm test

- The porosity and permeability of the eight core samples will be measured before and after conducting the core flooding test.

- The initial and final porosities and permeability of the eight core samples will be recorded.

- Then, the improved porosity and permeability ratio (IMPR) will be calculated.

- It is the ratio of the final porosity and permeability to the initial porosity and permeability (Shafiq et al. 2015; Shafiq and Ben Mahmud 2016).

- FESEM test

- The mineralogy of the core sample will be identified before and after conducting the core flooding test to investigate the presence of different minerals in it.

- FESEM is versatile and non-destructive. 
- The mineralogy change provides indication for the reaction of minerals with the acid combination (Shafiq and Ben Mahmud 2016).

- ICP analysis

- ICP will be used to measure the concentration of cations present in the injected acid system.

- The ions being analyzed are $\mathrm{Ca}, \mathrm{Mg}, \mathrm{Fe}, \mathrm{Si}$ and $\mathrm{Al}$ (Nasr-El-Din et al. 2013; Abdelmoneim and NasrEl-Din 2015).

- F-NMR analysis

- ${ }^{19}$ F-NMR will be used to investigate the reaction between clay minerals and the acid combination system.

- It is used in the detection of the chemical species in solution.

- F-NMR also determines the fluoride distribution in the chemical species present in the spent acid, hence provides information for the reaction kinetics and products (Ji et al. 2014).

- CT scan analysis

- CT scan will be used to investigate the extent of the acid penetration into the core sample.

- Before the core flooding treatment, the CT scan will show no channels or vugs in the core.

- However, acid penetration channels or wormholes are expected to be observed after core flooding.

- It will provide information on the wormhole propagation pattern in the core sample (Sayed and NasrEl-Din 2013).

\section{Significance of future research}

The future research will generate a new knowledge on reservoir stimulation technique, in the aspect of sandstone matrix acidizing using different acid combinations, which are HF and $\mathrm{HBF}_{4}$ in particular. It is intended to determine the optimum conditions for both $\mathrm{HF}$ and $\mathrm{HBF}_{4}$ to show a significant improvement in enhancing the porosity and permeability of a low-permeable sandstone formation reservoir at high temperatures. Moreover, it is also crucial to provide information about the effects of acid concentration, injection rate and the temperature of reservoir formation on acid penetration. Therefore, this research would be able to make a significant breakthrough in the oil and gas industry by diversifying the acid choice and concentration to optimize the sandstone matrix acidizing process at elevated temperatures.

\section{Concluding remarks}

In the past years, mud acid was highly acknowledged due to its efficiency in enhancing the porosity and permeability of sandstone matrix. This is because HF is unique and is the only acid that can dissolve silica minerals present in sandstone, whereas $\mathrm{HCl}$ is proven to be able to control precipitation during acidizing. However, rapid rate of reaction occurs and results in early consumption of acid when the well temperature increases to higher than $200^{\circ} \mathrm{F}$. This makes mud acid a drawback as it decreased the efficiency of acidizing. Mud acid is also highly corrosive and hazardous.

So, fluoroboric acid $\left(\mathrm{HBF}_{4}\right)$ is being proposed in the scope of future work. Numerous advantages were observed in $\mathrm{HBF}_{4}$ when compared to the mud acid. It causes greater increase in the permeability, less reduction in the mechanical strength of core plugs and has also significantly lower corrosiveness. $\mathrm{HBF}_{4}$ is more beneficial than conventional mud acid due to its retardation effect. However, there is no innovative discovery of the limitation of this retardation effect. Although $\mathrm{HBF}_{4}$ has a slow hydrolysis process to form $\mathrm{HF}$, its retardation effect is a function of temperature. This means that as the temperature increases, the retardation effect of $\mathrm{HBF}_{4}$ will be reduced until it reaches an optimum point of temperature. Hence, the persistence of $\mathrm{HBF}_{4}$ at high temperatures deserves detailed investigation in future to provide a more precise and reliable recommendation of acid choice between $\mathrm{HF}$ and $\mathrm{HBF}_{4}$.

Additionally, it is also important to evaluate other parameters during sandstone acidizing process, which will possibly affect the success rate of an acid stimulation operation such as the injection rate and acid concentration. By integrating the effects of temperature with these parameters, an optimization approach can be conducted. By comparing the effects of these parameters on $\mathrm{HBF}_{4}$ and HF, respectively, a clear understanding of suitable acid choice and treatment design at various conditions can be obtained. This is also crucial to ensure that the claimed benefits of $\mathrm{HBF}_{4}$ over conventional mud acid can be utilized effectively, without causing any negative stimulation performance.

In conclusion, it is recommended in the future that these two acids can be compared extensively by incorporating various governing parameters. Both $\mathrm{HF}$ and $\mathrm{HBF}_{4}$ are also proposed to be investigated using core flooding apparatus at higher temperatures of 60,80 and $100{ }^{\circ} \mathrm{C}$ for comparison. Various analyses such as Poro-Perm, FESEM, CT scan, ICP and ${ }^{19} \mathrm{~F}$ NMR as discussed in previous section can be carried out to test the efficiency of $\mathrm{HF}$ and $\mathrm{HBF}_{4}$, respectively. 
Acknowledgements The authors would like to gratefully extend their gratitude and acknowledgement to the Ministry of Higher Education (MOHE) Malaysia and Curtin University Malaysia for their financial support in this project. This study was supported by the Fundamental Research Grant Scheme (FRGS) (Grant no. FRGS 1044) and Faculty of Engineering and Science (FOES) in Curtin University Malaysia.

Open Access This article is distributed under the terms of the Creative Commons Attribution 4.0 International License (http://creativeco mmons.org/licenses/by/4.0/), which permits unrestricted use, distribution, and reproduction in any medium, provided you give appropriate credit to the original author(s) and the source, provide a link to the Creative Commons license, and indicate if changes were made.

\section{References}

Abdelmoneim SS, Nasr-El-Din HA (2015) Determining the optimum $\mathrm{HF}$ concentration for stimulation of high temperature sandstone formations. Society of Petroleum Engineers, Dallas

Aboud RS, Smith KL, Pachon F, Kalfayan L (2007) Effective matrix acidizing in high-temperature environments. Society of Petroleum Engineers, Dallas

Al-Dahlan MN, Nasr-El-Din HA, Al-Qahtani AA (2001) Evaluation of retarded HF acid systems. Society of Petroleum Engineers, Dallas

Al-Harbi BG, Al-Khaldi MH, AlDossary KA (2011) Interactions of organic-HF systems with aluminosilicates: lab testing and field recommendations. Society of Petroleum Engineers, Dallas

Al-Harbi BG, Al Dahlan MN, Khaldi MH (2012) Aluminum and iron precipitation during sandstone acidizing using organic-HF acids. Society of Petroleum Engineers, Dallas

Al-Harthy S, Fuller BOA, Hamzah MJ, Ismail ME, Parapat MI (2009) Options for high-temperature well stimulation. Oilfield Rev 4.20:52-53

Ali S, Frenier WW, Lecerf B, Ziauddin M, Kotlar HK, Nasr-el-din A, Vikane $\mathrm{O}$ (2004) Virtual testing: the key to a stimulating process. Oilfield Rev 16(1):58-68

Ali SA, Ermel E, Clarke J, Fuller MJ, Xiao Z, Malone B (2008) Stimulation of High-temperature sandstone formations from west africa with chelating agent-based fluids. Society of Petroleum Engineers, Dallas

Al-Shaalan TM, Nasr-El-Din HA (2000) Mathematical modeling of sandstone stimulation: a critical review of available models. NACE International, Houston

Andotra G (2014) Investigating the use of chelating agents for clay dissolution and sandstone acidizing purposes. Master's thesis. Texas A\&M University, Texas

Aneto N (2012) An in-depth investigation of an aluminum chloride retarded mud acid system on sandstone reservoirs. Master's thesis. Texas A\&M University, Texas

Ayorinde A, Granger C, Thomas RL (1992) The application of fluoboric acid in sandstone matrix acidizing: a case study. In: Presented at the 21 st annual convention of the Indonesian Petroleum Association

Bybee K (2003) Matrix acid stimulation. Society of Petroleum Engineers, Dallas

Cipolla CL (2003) Overview: well stimulation. Society of Petroleum Engineers, Dallas

Coulter G (2011) Technology focus: well stimulation. Society of Petroleum Engineers, Dallas

Coulter G (2012) Technology focus: well stimulation. Society of Petroleum Engineers, Dallas

Crowe C, Masmonteil J, Thomas R (1992) Trends in matrix acidizing. Oilfield Rev 4(4):22-40
Dehghani M (2010) Matrix acidizing stimulation. The 1st International Applied Geological Congress, Iran

Economides MJ, Hill AD, Ehlig-Economides C, Zhu D (2013) Petroleum production systems, 2nd edn. Prentice Hall, Upper Saddle River

Farley JT, Miller BM, Schoettle V (1970) Design criteria for matrix stimulation with hydrochloric-hydrofluoric acid. Society of Petroleum Engineers, Dallas

Feng P, Wang D, Liu G, Wang H, Economides MJ (2011) Sandstone reservoir stimulation using high-temperature deep-penetrating acid. Society of Petroleum Engineers, Dallas

Frenier W, Brady M, Al-Harthy S, Arangath R, Chan KS, Flamant N, Samuel M (2004) Hot oil and gas wells can be stimulated without acids. Society of Petroleum Engineers, Dallas

Garcia EAR, LaBlanc A, Beuterbaugh A, Calabrese T (2016) Developments in sandstone HF acidizing: HF fluid compatible with $\mathrm{Na}$ or K brines and carbonate-laden mineralogy for high temperatures $\left(360^{\circ} \mathrm{F}\right)$. Society of Petroleum Engineers, Dallas

Gidley JL (1985) Acidizing sandstone formations: a detailed examination of recent experience. Society of Petroleum Engineers, Dallas

Gomaa AM, Cutler J, Qu Q, Boles J, Wang X (2013) An effective single-stage acid system for sandstone formations. Society of Petroleum Engineers, Dallas

Hanafy AM, Nasr-El-Din HA (2016) NMR study to assess fines migration damage and its removal using regular mud acid in different sandstone cores. Society of Petroleum Engineers, Dallas

Hanafy A, Ali A, Nasr-El-Din HA, Heidari Z (2015) Evaluating the effects of acid stimulation treatment before and after fines migration on petrophysical properties in sandstone reservoirs. International petroleum technology conference

Hashem MK, Nasr-El-Din HA, Hopkins JA (1999) An experience in acidizing sandstone reservoirs: a scientific approach. Society of Petroleum Engineers, Dallas

Hill AD, Lindsay DM, Silberberg IH, Schechter RS (1981) Theoretical and experimental studies of sandstone acidizing. Society of Petroleum Engineers, Dallas

Hill AD, Sepehrnoori K, Wu PY (1994) Design of the HCl preflush in sandstone acidizing. Society of Petroleum Engineers, Dallas

Holman GB (1982) State-of-the-art well stimulation. Society of Petroleum Engineers, Dallas

Houseworth JE (2014) Advanced well stimulation technologies in California: an independent review of scientific and technical information, executive summary. California Council on Science and Technology. 978-1-930117-94-5\$4

Jaramillo OJ, Romero R, Ortega A, Milne AW, Rodrigues E (2010) Matrix acid systems for formations with high clay content. Society of Petroleum Engineers, Dallas

Ji Q, Zhou L, Nasr-El-Din HA (2014) Acidizing sandstone reservoirs using fines control acid. Society of Petroleum Engineers, Dallas

Ji Q, Zhou L, Nasr-El-Din H (2016) Acidizing sandstone reservoirs with aluminum-based retarded mud acid. Society of Petroleum Engineers, Dallas

Kalfayan LJ (2008) Production enhancement with acid stimulation, 2nd edn. PennWell, Tulsa

Kalfayan LJ, Metcalf AS (2000) Successful sandstone acid design case histories: exceptions to conventional wisdom. Society of Petroleum Engineers, Dallas

King GE (1986) Acidizing concepts-matrix vs. fracture acidizing. Society of Petroleum Engineers, Dallas

Kunze KR, Shaughnessy CM (1983) Acidizing sandstone formations with fluoboric acid. Society of Petroleum Engineers, Dallas

Lamb W (1998) Topics for production chemistry—high HF acid. Paris Meeting, March 10-12

Legemah MU, Gomaa A, Bilden D, Lowe C, Boles J, Qu Q, Li L (2015) Sequential injection process enhances acidizing 
treatment of high-temperature wells. Society of Petroleum Engineers, Dallas

LePage JN, De Wolf C, Bemelaar J, Nasr-El-Din HA (2009) An environmentally friendly stimulation fluid for high-temperature applications. Society of Petroleum Engineers, Dallas

Mahmoud MA (2011) Removing of formation damage and enhancement of formation productivity using environmentally friendly chemicals. Doctoral dissertation.. Texas A\&M University, Texas

Mahmoud MA, Nasr-El-Din HA, De Wolf C, Alex A (2011) Sandstone acidizing using a new class of chelating agents. Society of Petroleum Engineers, Dallas

Mahmoud MA, Nasr-El-Din HA, De Wolf CA (2015) High-temperature laboratory testing of illitic sandstone outcrop cores with $\mathrm{HCl}$-alternative fluids. Society of Petroleum Engineers, Dallas

McBride JR, Rathbone MJ, Thomas RL (1979) Evaluation of fluoboric acid treatment in the Grand Isle offshore area using multiple rate flow test. Society of Petroleum Engineers, Dallas

McLeod HO (1984) Matrix acidizing. Society of Petroleum Engineers, Dallas

Milligan M (1994) Well stimulation using acids. Petroleum Society of Canada, Alberta

Muecke TW (1982) Principles of acid stimulation. Society of Petroleum Engineers, Dallas

Nasr-El-Din HA (2013) HT stimulation fluid based on GLDA meets productivity, environmental need. Society of Petroleum Engineers, Dallas

Nasr-El-Din HA, Al-Nasser AH, Al-Habib NS, Jemmali M, Zoraia G, Sunbul A (2005) New methodology to effectively stimulate water disposal wells drilled in acid sensitive sandstone formations in Saudi Arabia. Society of Petroleum Engineers, Dallas

Nasr-El-Din HA, Zhou L, Al-Harbi Ghazi B (2013) Interactions of a sandstone acid systems with clays. Society of Petroleum Engineers, Dallas

Nevito Gomez J (2006) Design, set up, and testing of a matrix acidizing apparatus. Master's thesis. Texas A\&M University, Texas

O'Driscoll KP, Stolyarov S, Kalfayan L (2005) A review of matrix aciding sandstones in western Siberia Russia. Society of Petroleum Engineers, Dallas

Paccaloni G, Tambini M (1993) Advances in matrix stimulation technology. Society of Petroleum Engineers, Dallas

Parkinson M, Munk TK, Brookley JG, Caetano AD, Albuquerque MA, Cohen D, Reekie MR (2010) Stimulation of multilayered highcarbonate-content sandstone formations in West Africa using chelant-based fluids and mechanical diversion. Society of Petroleum Engineers, Dallas

Pituckchon A (2014) Further investigation of fluoboric acid in sandstone acidizing using ${ }^{11} \mathrm{~B}$ and ${ }^{19} \mathrm{~F}$ NMR. Master's thesis. Texas A\&M University, Texas

Portier S, André L, Vuataz FD (2007) Review on chemical stimulation techniques in oil. Centre for Geothermal Research, Neuchâtel

Rabie AI, Nasr-El-Din HA (2015) Effect of acid additives on the reaction of stimulating fluids during acidizing treatments. Society of Petroleum Engineers, Dallas

Reyes EA, Smith AL, Beuterbaugh A, Calabrese T (2015) GLDA/HF facilitates high temperature acidizing and coiled tubing corrosion inhibition. Society of Petroleum Engineers, Dallas

Rignol J, Ounsakul T, Kharrat W, Fu D, Teng LK, Lomovskaya I, Boonjai P (2015) Improved fluid technology for stimulation of ultrahigh-temperature sandstone formation. Society of Petroleum Engineers, Dallas

Rogers BA, Burk MK, Stonecipher SA (1998) Designing a remedial acid treatment for Gulf of Mexico deepwater turbidite sands containing zeolite cement. Society of Petroleum Engineers, Dallas

Sanchez T (2016) Operating manual, core flooding - V 1.5740. http:// www.stfrance.fr. Accessed 23 Mar 2016
Sayed MAI, Nasr-El-Din HA (2013) Acid treatments in high temperature dolomitic carbonate reservoirs using emulsified acids: a coreflood study. Society of Petroleum Engineers, Dallas

Schechter RS (1992) Oil well stimulation. Prentice Hall, Englewood Cliffs

Schmid W, Martin A, Palacios JM (2016) Comprehensive approach of reservoir characterization has allowed successful stimulation of sandstone formations in Bachaquero Field-Lake Maracaibo, Venezuela. Society of Petroleum Engineers, Dallas

Shafiq MU, Ben Mahmud HK (2016) An effective acid combination for enhanced properties and corrosion control of acidizing sandstone formation. IOP Conf Ser Mater Sci Eng 121:012002

Shafiq MU, Mahmud HB (2017) Sandstone matrix acidizing knowledge and future development. J Pet Explor Prod Technol 7:12051216. https://doi.org/10.1007/s13202-017-0314-6

Shafiq MU, Shuker MT (2013) Finding suitable acid for acidizing of low permeable sandstone formation: a research. Society of Petroleum Engineers, Dallas

Shafiq MU, Shuker MT, Kyaw A (2013a) Comparison of using combination of acetic acid and hydrochloric acid with only hydrochloric acid as matrix pre flush. Int J Pet Geosci Eng (IJPGE) 1(1):41-49

Shafiq MU, Shuker MT, Kyaw A (2013b) Performance prediction of acids on sandstone acidizing. ASJ Int J Adv Sci Res Rev (IJASRR) 1(2):07-12

Shafiq MU, Shuker MT, Kyaw A (2014) Performance comparison of new combinations of acids with mud acid in sandstone acidizing. RJASET 7(2):323-328

Shafiq MU, Ben Mahmud HK, Hamid MA (2015) Comparison of buffer effect of different acids during sandstone acidizing. IOP Conf Ser Mater Sci Eng 78:012008

Shuchart CE (1997) Chemical study of organic-HF blends leads to improved fluids. Society of Petroleum Engineers, Dallas

Shuchart CE, Gdanski RD (1996) Improved success in acid stimulations with a new organic-HF system. Society of Petroleum Engineers, Dallas

Smith CF, Hendrickson AR (1965) Hydrofluoric acid stimulation of sandstone reservoirs. Society of Petroleum Engineers, Dallas

Svendsen OB, Kleven R, Hartley IPR, Aksnes N (1992) Stimulation of high-rate gravel-packed oil wells damaged by clay and fines migration: a case study, Gullfaks Field, North Sea. Society of Petroleum Engineers, Dallas

Templeton CC, Richardson EA, Karnes GT, Lybarger JH (1975) Selfgenerating mud acid. Society of Petroleum Engineers, Dallas

Thomas RL, Crowe CW (1978) Single-stage chemical treatment provides stimulation and clay control sandstone formations. Society of Petroleum Engineers, Dallas

Thomas RL, Crowe CW (1981) Matrix treatment employs new acid system for stimulation and control of fines migration in sandstone formations. Society of Petroleum Engineers, Dallas

Thomas RL, Nasr-El-Din HA, Lynn JD, Mehta S, Zaidi SR (2001) Precipitation during the acidizing of a HT/HP illitic sandstone reservoir in Eastern Saudi Arabia: a laboratory study. Society of Petroleum Engineers, Dallas

Thomas RL, Nasr-El-Din HA, Lynn JD, Mehta S, Muhareb M, Ginest $\mathrm{N}$ (2002a) Channel vs. matrix sandstone acidizing of a HT/HP reservoir in Saudi Arabia. Society of Petroleum Engineers, Dallas

Thomas RL, Nasr-El-Din HA, Mehta S, Hilab V, Lynn JD (2002b) The impact of $\mathrm{HCl}$ to $\mathrm{HF}$ ratio on hydrated silica formation during the acidizing of a high temperature sandstone gas reservoir in Saudi Arabia. Society of Petroleum Engineers, Dallas

Tuedor FE, Xiao Z, Frenier WW, Fu D, Salamat G, Davies SN, Lecerf B (2006) A breakthrough fluid technology in stimulation of sandstone reservoirs. Society of Petroleum Engineers, Dallas

Van Domelen MS, Jennings AR (1995) Alternate acid blends for HPHT applications. Society of Petroleum Engineers, Dallas

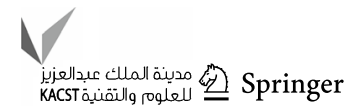


Van Domelen MS, Reddingius AA, Faber MJ, Buijse MA (1997) Hightemperature acid stimulation offshore the Netherlands. Society of Petroleum Engineers, Dallas

Veldkam JGH, Boxem TAPT (2015) Sector outlook: geothermal power increase in the Netherland by enhancing the capacity. TNO

Wang XL, Qu Q, Boles JL, Gomaa AM, Cutler JL (2013) Matrix stimulation: an effective one-step sandstone acid system. Society of Petroleum Engineers, Dallas

Wehunt CD, Van Arsdale H, Warner JL, Ali SA (1993) Laboratory acidization of an eolian sandstone at 380F. Society of Petroleum Engineers, Dallas

Williams BB, Gidley JL, Schechter RS (1979) Acidizing fundamentals, vol 8. Society of Petroleum Engineers, United States

Xie T, Li C, Pournik M, Zhu D, Hill AD, Devine C (2005) A laboratory and modeling investigation of acid-created wormholes in sandstones. Society of Petroleum Engineers, Dallas

Yang F (2012) Acidizing of Sandstone Reservoirs Using HF and Organic Acids. Master's thesis. Texas A\&M University, Texas

Yang F, Nasr-El-Din HA, Al-Harbi BM (2012a) Acidizing sandstone reservoirs using $\mathrm{HF}$ and formic acids. Society of Petroleum Engineers, Dallas
Yang F, Nasr-El-Din HA, Harbi BA (2012b) Acidizing sandstone reservoirs using HF and organic acids. Society of Petroleum Engineers, Dallas

Zeit B (2005) Stimulation of sandstone reservoirs. SPE technology transfer workshop (TTW). A presentation

Zhou L, Nasr-El-Din HA (2013) Acidizing sandstone formations using a sandstone acid system for high temperatures. Society of Petroleum Engineers, Dallas

Zhou L, Nasr-El-Din HA (2016) Phosphonic-based hydrofluoric acid: interactions with clay minerals and flow in sandstone cores. Society of Petroleum Engineers, Dallas

Zhou X, Zhang SC, Zhang X, Wang F, Lin H (2016) Core-scale experimental and numerical investigation on fluroboric acidizing of a sandstone reservoir. Energy Technology

Publisher's Note Springer Nature remains neutral with regard to jurisdictional claims in published maps and institutional affiliations. 